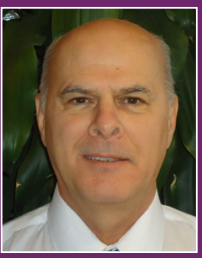

René Roy was born in Québec (Canada). He holds a Canadian Research Chair in Therapeutic Chemistry in the Department of Chemistry of the Université du Québec à Montréal (Qc, Canada) since 2004 After is Ph. D., obtained in 1980 from the Université de Montréal in carbohydrat chemistry under Pr. Stephen Hanes chemistry under Pr. Stephen Hanessian, he joined the National Research Council of Canada in Ottawa (Canada) from 1980-1985. He was then professor in the Department of Chemistry at the University of Ottawa from 19852002. He has been the recipient of the 2003 Melville L. Wolfrom Award from the ACS Division of Carbohydrate Chemistry for his cond contributions in the design of vaccines and glycodendrimers. He has published over 300 publications and has contributed to the development of two commercial carbohydrate-based vaccines. His actual interests are in multivalent carbohydrate protein interactions and in nanomedicines.
*Correspondence: René Roy. PharmaQAM - Department of Chemistry, Université du Québec à Montréal, P.O. Box 8888 Succ. Centre-ville, Montréal, Québec, Canada H3C 3P8. E-mail: roy.rene@uqam.ca

\section{Glycodendrimers: versatile tools for nanotechnology}

\author{
René Roy,", Tze Chieh Shiao ${ }^{1}$, Kate Rittenhouse-Olson ${ }^{2}$
}

${ }^{1}$ PharmaQAM - Department of Chemistry, Université du Québec à Montréal, Montréal, QC, Canada, ${ }^{2}$ Department of Biotechnical and Clinical Laboratory Sciences, University of Buffalo, Buffalo, NY, United States of America

Combining nanotechnology with glycobiology has triggered an exponential growth of research activities in the design of novel functional bionanomaterials (glyconanotechnology). More specifically, recent synthetic advances towards the tailored and versatile design of glycosylated nanoparticles namely glyconanoparticles, considered as synthetic mimetics of natural glycoconjugates, paved the way toward diverse biomedical applications. The accessibility of a wide variety of these structured nanosystems, in terms of shapes, sizes, and organized around stable nanoparticles have readily contributed to their development and applications in nanomedicine. In this context, glycosylated gold-nanoparticles (GNPs), glycosylated quantum dots (QDs), fullerenes, single-wall natotubes (SWNTs), and selfassembled glycononanoparticles using amphiphilic glycopolymers or glycodendrimers have received considerable attention to afford powerful imaging, therapeutic, and biodiagnostic devices. This review will provide an overview of the most recent syntheses and applications of glycodendrimers in glycoscience that have permitted to deepen our understanding of multivalent carbohydrate-protein interactions. Together with synthetic breast cancer vaccines, inhibitors of bacterial adhesions to host tissues including sensitive detection devices, these novel bionanomaterials are finding extensive relevance.

Uniterms: Dendrimer. Glycodendrimer. Vaccine. Bacteria. Nanoparticles. E. coli. Lanthanides.

A combinação de nanotecnologia com glicobiologia tem desencadeado o crescimento exponencial de atividades de pesquisa em desenvolvimento de novos biomateriais funcionais (gliconanotecnologia). Mais especificamente, recentes avanços sintéticos para o planejamento sob medida e versátil de nanopartículas glicosiladas, ou seja, gliconanopartículas, consideradas como miméticos sintéticos de glicoconjugados naturais, prepararam o caminho para diversas aplicações biomédicas. A acessibilidade da grande variedade destes nanossistemas estruturados, em termos de forma, tamanho e organização, tem prontamente contribuído para seu desenvolvimento e aplicações em nanomedicina. Neste contexto, nanopartículas de ouro glicosiladas (do inglês, GNPs), pontos quânticos glicosilados (do inglês, QDs), fulerenos, nanotubos de parede simples (do inglês, SWNTs) e gliconanopartículas autoconstruídas usando glicopolímeros anfifílicos ou glicodendrímeros têm recebido considerável atenção para originar poderosos instrumentos de imagem, terapêutico e de biodiagnóstico. Esta revisão fornecerá a visão global das mais recentes sínteses e aplicações de glicodendrímeros em glicociência que têm permitindo aprofundar nosso conhecimento das interações multivalentes proteína-carboidrato. Estes novos biomateriais estão sendo considerados de grande relevância, junto com vacinas sintéticas de câncer de mama, inibidores de adesão bacteriana em tecidos hospedeiros incluindo instrumentos de detecção sensível.

Unitermos: Dendrímeros. Glicodendrímeros. Vacina. Bactéria. Nanopartícula. E.coli. Lantanídeos. 


\section{INTRODUCTION}

\section{Nanometric glycoconjugates}

Biologically relevant sugar residues, linked to dendritic scaffolds and Nanoparticles (NPs), are becoming widely used as multivalent carbohydrate platforms toward biomedical applications. The globular shapes and nanometer sizes of NPs constitute efficient multivalent glycomimetics possessing greatly improved binding properties to their cognate protein receptors. In addition, different therapeutic molecules covalently bound to a single nanoparticle provide hybrid glyconanoparticles useful as biosensors, drug targeting devices, and imaging (Wang et al., 2010). Moreover, the stability, cytotoxicity and electronic, optical, and magnetic properties of NPs can be readily fine tuned. The sizes and shapes of NPs were shown to take part in several vital functions in their in vivo characteristics. For instance, liver, renal clearance, and mononuclear phagocyte uptake constitute just a few examples wherein the advantages of NPs could be targeted. Intracellular delivery is predominantly effected by the NPs charges together with surface groups specialized toward cellular receptors necessary for cells' nutrition or simply by one of the endocytic mechanism. Additionally, surface groups functionalization also play major factor toward stability, toxicity and long-term circulation of NPs. Poly(ethylene glycol) and carbohydrates including mono and polysaccharides are often used to reduce the toxicity and to improve the long-term blood circulation of NPs.
For chemotherapy, drugs NPs conjugates have the additional intrinsic ability of being more readily accumulated in tumor tissues due to the enhanced permeability and retention (EPR) effect of the tumor vasculature. The increased vascular permeability of NPs by the tumor blood vessels and ineffective lymphatic drainage can lead to NPs accumulation in the tumor. As such, nanoparticles conjugated to carbohydrates could be effective chemotherapeutic agents against cancers and viral/bacterial infections that use host glycans as adhesion principles. This subject will be extensively examined throughout this review.

The combination of glycobiology and nanotechnology has triggered a rapid growth of research activities in the design of novel functional bionanomaterials (glyconanotechnology). More specifically, recent synthetic advances towards the tailored design of glyconanoparticles, paved the way toward diverse biomedical applications. The accessibility of a wide variety of these structured nanosystems, in terms of shapes, sizes, and organized around stable nanoparticles have readily contributed to their development and applications in nanomedicine (Doane, Burda, 2012; Kottari et al., 2013). In this context, glycosylated gold-nanoparticles (GNPs), glycosylated quantum dots (QDs), fullerenes, single-wall natotubes (SWNTs), and self-assembled glyconanoparticles using amphiphilic glycopolymers or glycodendrimers have received considerable attention to afford powerful imaging, therapeutic, and biodiagnostic devices (Figure 1).

This review will provide an overview of the most recent syntheses and applications of glyconanoparticles

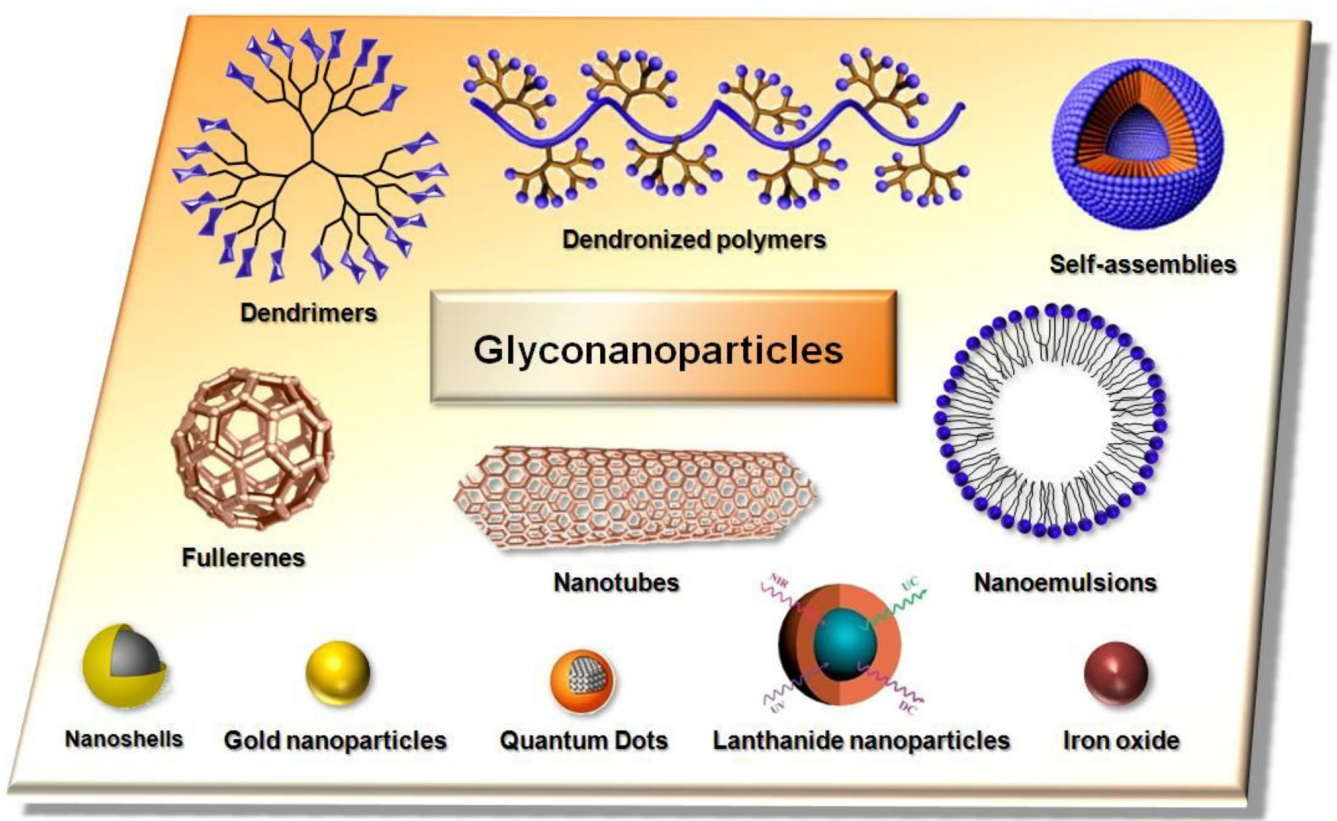

FIGURE 1- Schematic representation of accessible multivalent glyconanoparticles reviewed in this chapter. 

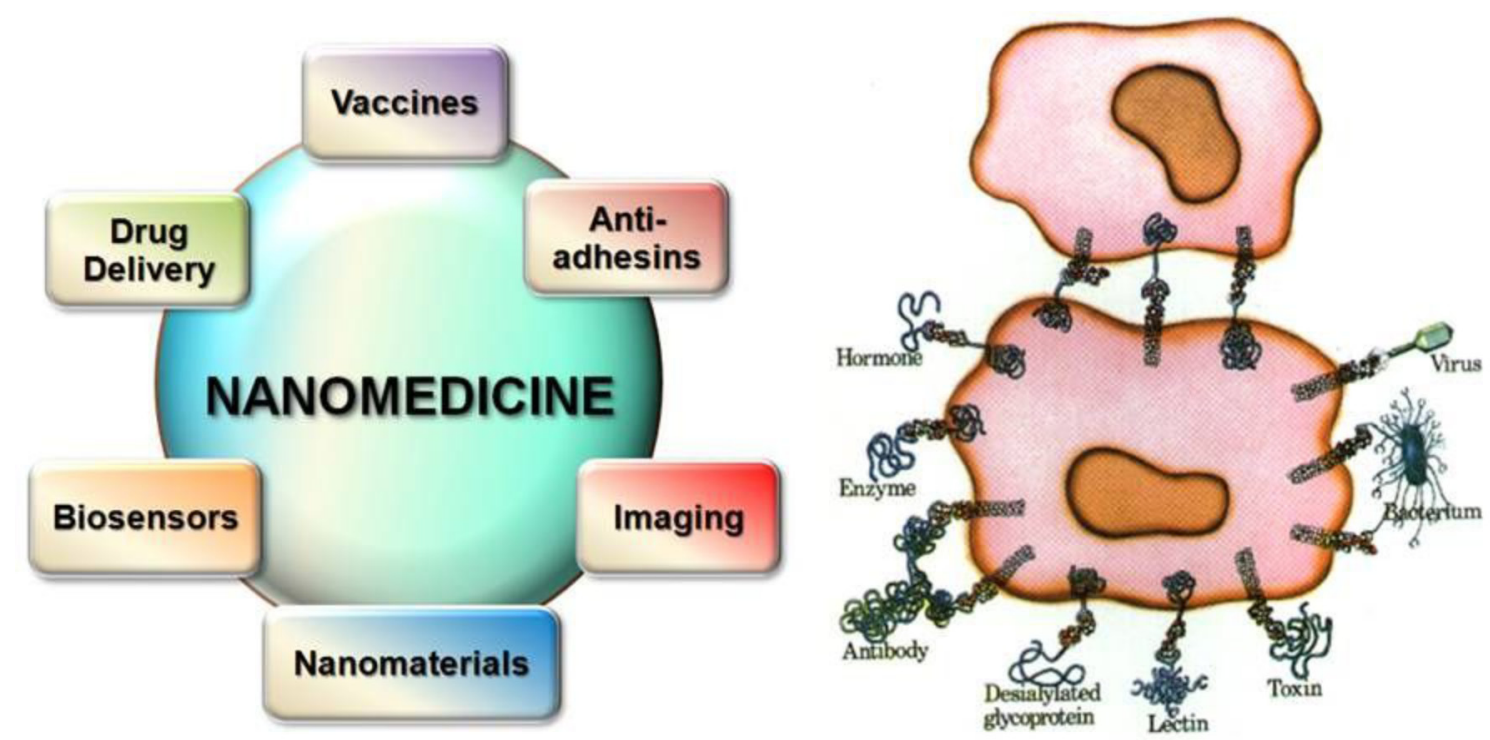

FIGURE 2- Left: Overview of applications involving glyconanoparticles. Right: Cell surface carbohydrates are involved in several pathogenicities including cancer and bacterial adhesions. Adapted from: http://www.glycotech.com (formerly BioCarb Chemicals).

in glycoscience that have permitted to deepen our understanding of multivalent carbohydrate-protein interactions. A particular emphasis will be directed to cancer vaccines together with inhibitors of bacterial adhesions of uropathogenic $E$. coli to host tissues. Figure 2 (left) illustrates the many different fields into which glyconanoparticles have began to play major roles that span from drug delivery, imaging, nanomaterial sciences, and biosensors, besides the two applications discussed below (De La Fuente, Penadés, 2006; Cipolla, Peri, Airoldi, 2008; Garcia, Marradi, Penadés, 2010; Narrain, 2011; Garcia et al., 2011; El-Boubbou, Huang, 2011; Marradi et al., 2013 ). This review will also briefly described our ongoing activities in the area of sugar-based gold nanoparticles and up converting lanthanide NPs. The physiological roles played by cell surface carbohydrates are several folds. As seen in Figure 2 (right), glycans can be responsible for cell cell interactions, pathogenic infections, cancer cell proliferation and metastasis. Several of these carbohydrate-based recognition phenomena may also lead to apoptosis. The interactions are highly dependent on the sugar densities and multivalency has been frequently evoked to rationalize the detrimental pathophysiological outcome.

\section{Tumor associated carbohydrate antigens}

Carbohydrates are T-cell independent antigens since they are incompetent to trigger the participation of T-helper cells (Danishefsky, Allen, 2000; Roy, 2004; Becker et al., 2006; Liakatos, Kunz, 2007; Roy, 2008; Wilson et al., 2008; Guo, Boons, 2009; Guo, Wang,
2009; Westerlind, Kunz, 2011; Morelli, Poletti, Lay, 2011; Galan, Benito-Alifonso, Watt, 2011; Roy, Shiao, 2011). Consequently, they cannot induce immune cell proliferation, antibody class switch and affinity/specificity maturation on their own, as opposed to peptides and proteins that are T-cell dependent antigens. Paradoxically, the major successful developments achieved with carbohydrate-based vaccines stem from the fact that, when properly conjugated to protein carriers, bacterial capsular polysaccharides (CPS) became capable of acquiring the requisite immunochemical ability. The four known carbohydrate antigen uptake mechanisms by antigen presenting cells (APCs) are well documented (Cobb, Kasper, 2005; Icart et al., 2008). The key to successful vaccines resulted from the fact that the common protein carriers contained at least one $\sim 15$-amino acids sequence ( $T$ cell epitopes) known to bind strongly to Major Histocompatibility Complex (MHC). Because B-cells possess surface immunoglobulins (Igs) that bind to multivalent carbohydrate antigens such as polymers and polysaccharides, it was anticipated that glycodendrimers (Chabre, Roy, 2009; Chabre, Roy, 2010) could also bind to these Igs and trigger signaling events leading to the production of low affinity and low specificity IgM antibodies. Moreover, some APCs express mannopyranoside binding receptors (lectins) known as DC-SIGN (Dendritic Cell-Specific Intercellular adhesion molecule3-Grabbing Non-integrin) also known as CD209 (Cluster of Differentiation 209) (Figdor, Van Kooyk, Adema, 2002). DC-SIGN on macrophages and dendritic cells recognizes and binds to mannose type carbohydrates, a 
class of pathogen associated pattern recognition receptors (PRRs) commonly found on viruses, bacteria and fungi. These binding interactions activate endocytosis and phagocytosis. Consequently, mannoside-bearing glycodendrimers are becoming "cargo molecules" to deliver other antigens (Chabre, Roy, 2012).

The other APCs uptake mechanisms are based on Toll-like receptors (TLRs) (Spohn et al., 2004). Known human Toll-like receptors constitute a family of ten protein members recognizing a wide variety of microbial lipophilic molecules (Park et al., 2009). One of which has particularly retained the attention of glycochemists, the TLR2 receptor (Kang et al., 2009). Another entry mechanism was also recently identified wherein zwitterionic polysaccharides (ZPS) could invoke, on their own, MHC class II-mediated CD4 ${ }^{+} \mathrm{T}$-cell responses in the absence of protein carriers (Avci, Kasper, 2010). Hence, recent reports are now emerging describing the covalent attachment of carbohydrate epitopes to such carriers, including one of the tumor associated carbohydrate antigen presented herein (De Silva et al., 2009). In this review, a description of various "glycodendrimers" (in a wide sense) constructs will be described concentrating on the most actively pursued vaccine candidates against tumor associated carbohydrate antigens (TACAs).

\section{GLYCODENDRIMER VACCINES}

The glycoproteins and glycolipids of the outer cell membranes of cancer cells over express particular $O$-glycans (Ragupathi, 1996; Hakomori, 2001). The glycoproteins constitute a family of proteins collectively known as mucins (MUC) with MUC1 representing the most widely investigated (Springer, 1984). These glycoproteins are heavily glycosylated on normal cells while limited $O$-glycosylations on cancer cells have been clearly demonstrated (Figure 3). Gangliosides (GM2, GD2, GD3) and neutral glycolipids (globo-H and Lewis ${ }^{y}$ ) on epithelial tumor cells of breast, lung, colon, bladder, and prostate are also considerably altered both in number and in structures (Livingston, 1995; Roy, 2004; Freire et al., 2006; Franco, 2008; Roy, 2008; Roy, Shiao, 2011). In the tumorassociated carbohydrate antigens (TACAs) of mucins, a down-regulation of a key glycosyltransferase triggers the accumulation of shorter glycans, the most common being the $\mathrm{T}_{\mathrm{N}}$ - and the $\mathrm{TF}$-antigens $(\mathrm{TF}=$ Thomsen-Friedenreich $)$, respectively. In healthy tissues, the active glycosyltransferase enzymes are responsible for a much more complex pattern of glycosylation (Figure 4). The consequence of these altered glycosylation profiles results in the over accumulation of TACAs which are otherwise cryptic (masked) on healthy tissues. MUC1 is a membrane-bound mucin and is found in more than $90 \%$ of breast carcinomas (Hattrup, Gendler, 2008). Consequently, most efforts to provide classical carbohydrate-based vaccines have been devoted to the above antigens and the related ones (Figure 3) (Ragupathi, 1996; Livingston, Ragupathi, 1997; Finn, 2003; Bast Jr et al., 2005).

Hence, the immediate target in prophylactic vaccine preparations was to trigger humoral immunity, i.e. stimulation of long lasting, high affinity antibodies, preferably of the IgG isotypes against the carbohydrate antigens. Several groups have developed systematic research projects aimed at the synthesis of various vaccine compositions (Livingston, 1995; Danishefsky, Allen, 2000; Kudryashov et al., 2001; Roy, 2004; Spohn et al., 2004; Freire et al., 2006; Liakatos, Kunz, 2007; Roy, 2008; Franco, 2008; Guo, Wang, 2009; Roy, Shiao, 2011). In spite of the limited success encountered with traditional vaccine formulations based on vaccine carriers harboring the
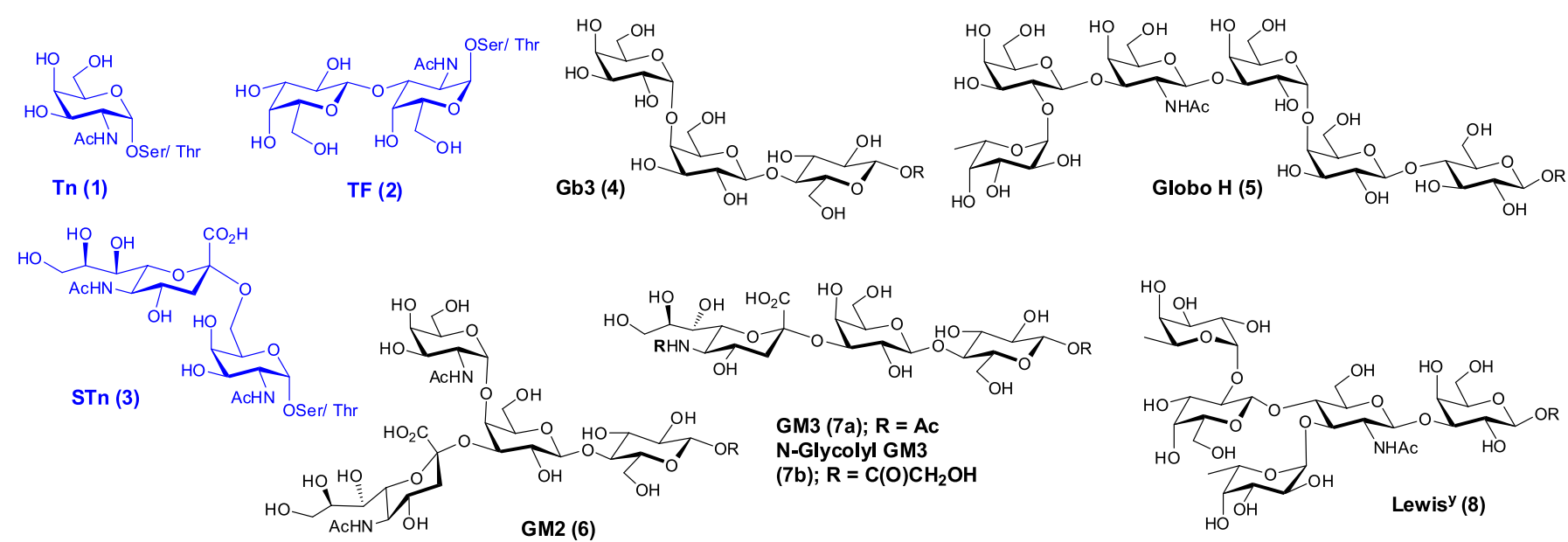

FIGURE 3 - Typical structures of representative TACAs from glycoproteins (blue) and glycolipids accumulated on cancer cells. 


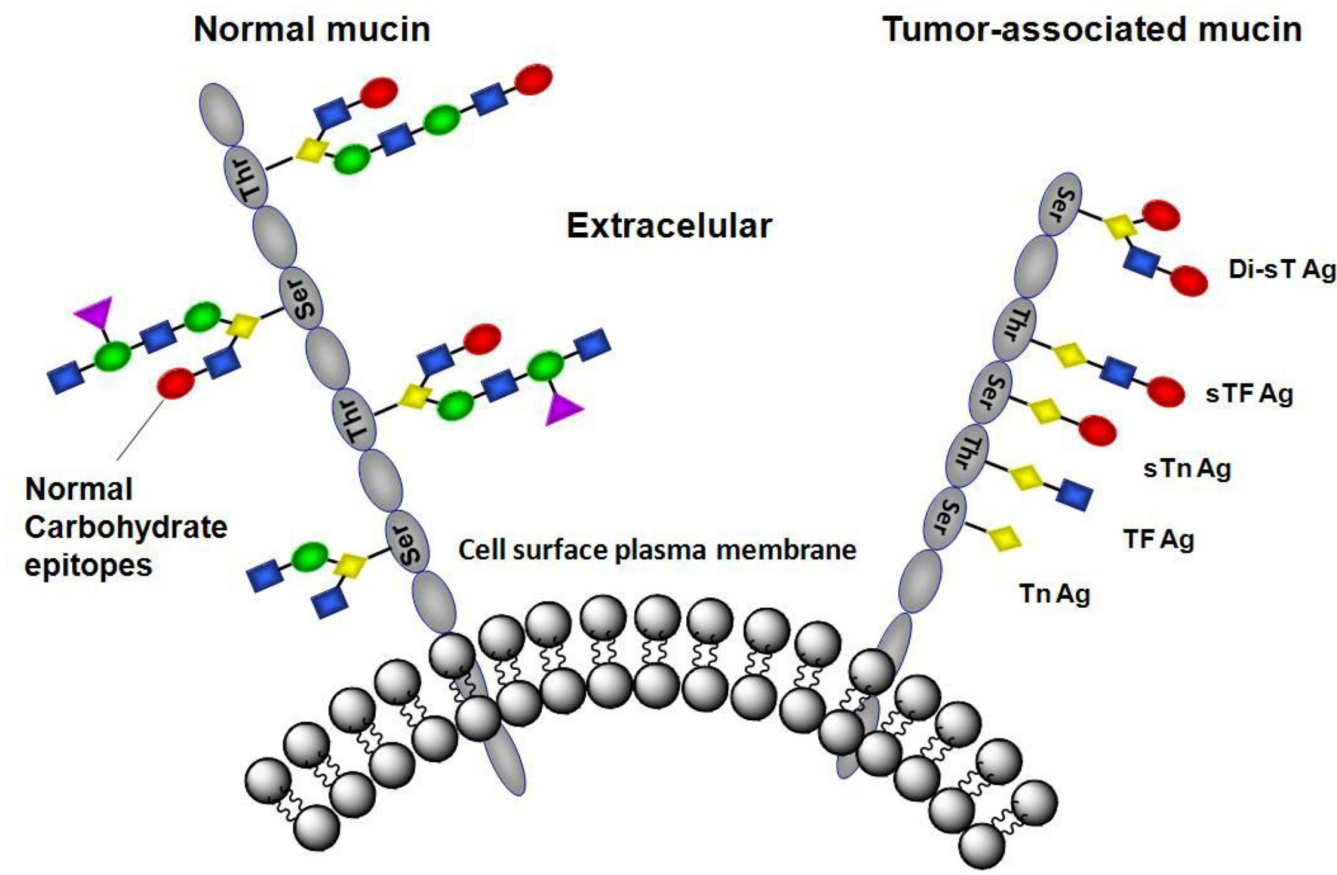

FIGURE 4 - Carbohydrate structures of mammalian cell surface mucins in healthy and cancer cells. Glycosylation patterns are much more elaborated in healthy mucins, thus masking key tumor associated carbohydrate antigens that become heavily exposed in tumors.

above carbohydrate antigens (Koganty, Yalamati, Jiang, 2008), considerable efforts have been recently devoted to the chemical design of glycodendrimers. These facets are further contributing to the need of well defined chemical constructs (Kaiser et al., 2010).

\section{Syntheses of vaccines, screening antigens, and glycodendrimers}

Mouse monoclonal antibodies (MAb) against the TF-Ag (2) to be used in evaluating the relative affinity of glycodendrimers were generated using a protein conjugate (17) (Rittenhouse-Diakun et al., 1998; Baek, Roy, 2000; Donovan et al., 2000; Baek, Roy, 2001a,b; Baek, Rittenhouse-Olson, Roy, 2001; Roy, Baek, Rittenhouse-Olson, 2001; Baek, Roy, 2002a,b). The vaccine was prepared from an $N$-acrylamido derivative (11) of an amino-ending TF intermediate derived from 9 (Baek, Rittenhouse-Olson, Roy, 2001) using 1,4 -conjugate addition from the $\varepsilon$-amino groups of the lysine residues of either bovine serum albumin (BSA) or the more immunogenic tetanus toxoid (TT) (Figure 5) (Rittenhouse-Diakun et al., 1998). A glycopolymer was also prepared to screen the above MAb and to serve as model cell surface mucin for solid-phase competitive immunoassays (Baek, Roy, 2000; Donovan et al., 2000; Baek, Roy, 2001a;). In this way, two monoclonal anti- bodies were selected for binding specificity and affinity studies. One was an IgM, while the selected IgG was of the IgG3 subfamily (JAA-F11) (Rittenhouse-Diakun et al., 1998). Dendritic scaffolds made of poly(amidoamine) (PAMAM (12)) (Figure 5), poly(propylene imine), $\mathrm{N}, \mathrm{N}$-bis(acrylamidoacetic acid) (not shown), and finally hyperbranched L-lysine were used to construct relatively small glycodendrimers bearing TF-antigen moieties (18, 19) (Baek, Roy, 2002a,b). Few glycodendrimers were also linked to fluorescein and biotin probes to generate ligand 20 that can be used to detect $\mathrm{TF}-\mathrm{Ag}$ receptor sites (Figure 6).

With these tools in hand, the required GlycoPAMAM dendrimers bearing the TF-Ag (13-16) were next prepared by amide bond formation between TF-Ag acid (10) and PAMAM dendritic cores (12) to generate G0 to $\mathrm{G} 3$ ( $\mathrm{n}=4$ to 32$)$ glycodendrimers (13-16) (Figure 5) (Baek, Rittenhouse-Olson, Roy, 2001; Baek, Roy, 2002a,b;).Analogously, several other TF-glycodendrimers were constructed, including those built on hyperbranched L-Lysine (18, 19) (Figure 6) (Baek, Roy, 2001b).

The relative potencies of the TF-glycodendrimer families (13-16) to inhibit the binding of mouse monoclonal IgG antibody to ELISA plate coated TF-copolymer was determined using goat anti-mouse monoclonal IgG and the results are shown in Table I. For the glycoPAMAMs, the degree of inhibition was proportional to the conjugate 
valencies which showed maximum inhibition whith the 32-mer 16 (G3). The concentrations of TF-PAMAMs to give $50 \%$ inhibition $\left(\mathrm{IC}_{50}\right)$ of the antibody-binding to the coated TF-copolymer were 5.0, 2.4, 1.4, and $0.6 \mathrm{nM}$

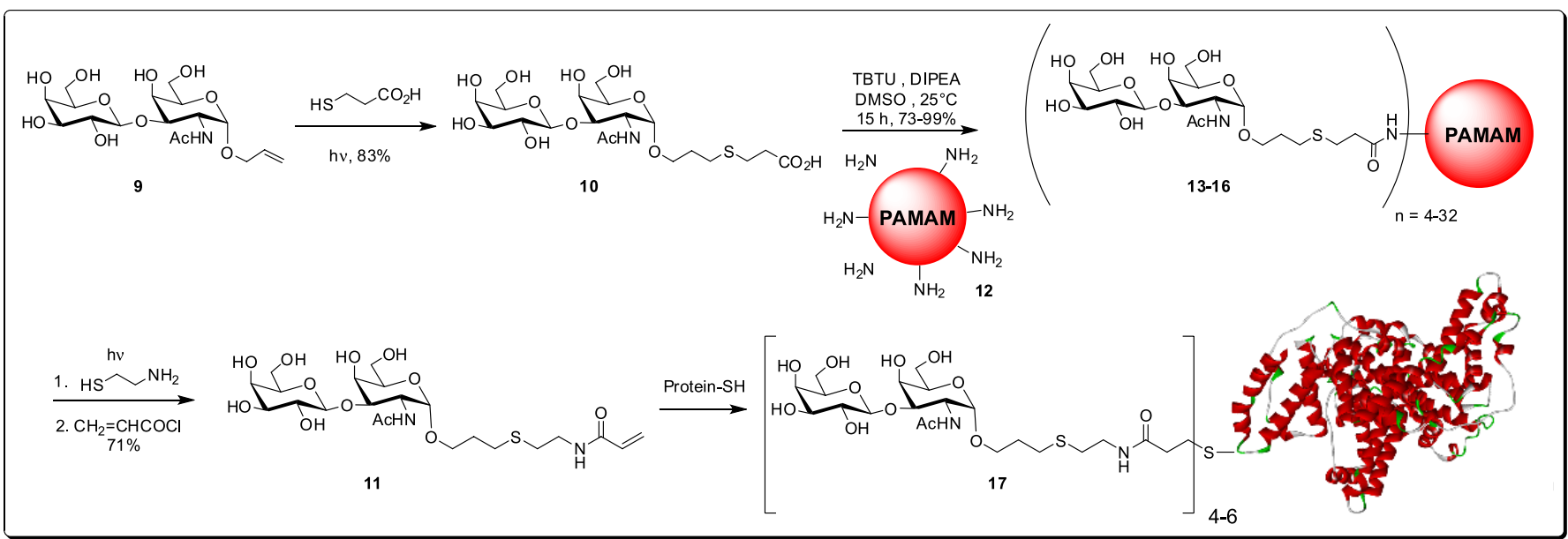

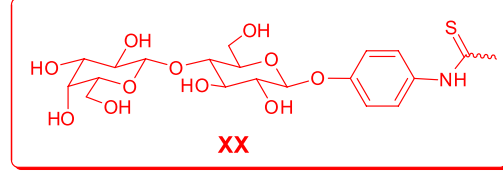

(c)

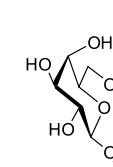

(OH<smiles>OCC(O)C(O)C(O)O</smiles>



\section{,}


for conjugates G0-G3 (13-16), respectively where the monomeric TF-Ag (9) required $2.3 \mu \mathrm{M}$. These values represent 460-, 960-, 1700- and 3800-folds enhancement of inhibitory potencies over that of the TF-monomer. By comparison to the $N, N$-bis(acrylamidoacetic acid)-based dendrimer series (not shown) (Roy, Baek, RittenhouseOlson, 2001), the dimer showed the poorest inhibitory value $\left(\mathrm{IC}_{50} 174 \mathrm{nM}\right)$, while the two homologous tetramers were approximately equipotent with $\mathrm{IC}_{50}$ of $18 \mathrm{nM}$ and the corresponding hexamer showed a noticeable decrease in affinity with $\mathrm{IC}_{50}$ value at $48 \mathrm{nM}$. For that series and on a per TF-Ag basis, the tetramers were the most potent with $\sim 31$-fold enhancement over that of the monomer. When compared together, the glycoPAMAM series G0-G3 $(\mathrm{n}=4-32)(\mathbf{1 3 - 1 6}$, Figure 5) showed the best value with overall 3.7-fold better binding ability over the $N, N^{\prime}$ bis(acrylamidoacetic acid)-based dendrimer series. The explanation for these observations is not straightforward but could partly be due to a slightly longer distance between the aglyconic oxygen and the branching fifteen atoms for PAMAMs in comparison to the nine atom linkers of the later, which may provide better accessibility of the TF-Ag for the receptor sites within the antibody combining sites. Interestingly, these results confirmed earlier findings (Roy, Baek, Rittenhouse-Olson, 2001) illustrating that tetrameric TF-Ag clusters may represent the optimum size for an antibody-glycocluster inhibition. The protein binding properties of these glycodendrimers were also evaluated using the plant lectin from Arachis hypogaea (peanut lectin) which constitutes a perfect antibody mimic, albeit tetravalent (Baek, Roy, 2002b).

It is also worth mentioning that while these TFdendrimers were highly antigenic, that is, they could strongly bind to antibodies, they all failed to illicit any immune response hence, they were shown to be nonimmunogenic (Toyokuni, Singhal, 1995). In other words, potent synthetic carbohydrate antigens may represent poor immunogens. The lack of immunogenicity was also confirmed when hyperbranched L-lysine were used as scaffolding dendrimers $(\mathbf{1 8}, \mathbf{1 9})$ (Figure 6) (Baek, Roy, 2001b). These observations can now be readily rationalized on the basis that, even when TACAs are presented as multivalent entities, they lack immunocompetent molecular entities (pattern recognition receptor ligands, as described above. Another noteworthy applications was found with a TF-linked poly-L-Lysine tetrameric dendron (18) onto which was anchored a biotin probe to provide $\mathbf{2 0}$ (Figure 6). Dendron 20 was found very useful in enzyme linked immunosorbent assays (ELISA) as it could be anchored to solid-phase through streptavidin binding for antibody capture (Baek, Roy, 2001b; Baek, Roy, 2002a) (Figure 7). Curiously and despite their apparent hydrophilicity, the TF-PAMAM dendrimers were also capable to directly coat the surface of hydrophobic ELISA plates (Baek, Roy, 2002b).

However, when conjugated to effective immunogenic protein carriers, the TF-antigen together with its shorter $\mathrm{T}_{\mathrm{N}}$-antigen ( $\alpha$-GalNAc-O-Ser/Thr) precursor as well as their sialylated counterparts (see Figure 3) were strongly immunogenic (Toyokuni et al., 1994). For instance, natural asialoovine submaxillary mucin (A-OSM), known to contain almost exclusively $\mathrm{T}_{\mathrm{N}}$ antigens, provided protection against challenge with a highly invasive mouse mammary carcinoma. The vaccine also induced in vitro proliferation of $\mathrm{CD} 4^{+} \mathrm{T}$ lymphocytes, thus indicating cellular immunity and protection. In addition, recent findings also suggested

TABLE I - Relative inhibitory potencies $\left(\mathrm{IC}_{50}{ }^{\prime} \mathrm{s}\right)$ of various TF-antigen dendrimers to mouse monoclonal antibody $\left(\mathrm{IgG}_{3}\right)$ binding to coated TF-copolymer

\begin{tabular}{lcc}
\hline Compound & IC $_{\mathbf{5 0}}(\mathbf{n M})^{\mathbf{a}}$ & Relative potency $^{\mathbf{a}}$ \\
\hline Monomer & 2300 & 1 \\
$\mathbf{1 3}$ PAMAM (G0) (4-mer) & $5.0(20.0)$ & $460(115)$ \\
$\mathbf{1 4}$ PAMAM (G1) (8-mer) & $2.4(19.2)$ & $960(120)$ \\
$\mathbf{1 5}$ PAMAM (G2) (16-mer) & $1.4(22.4)$ & $1700(106)$ \\
$\mathbf{1 6}$ PAMAM (G3) (32-mer) & $0.6(19.2)$ & $3800(119)$ \\
dimer $^{\mathrm{b}}$ & $174(347)$ & $13.3(6.6)$ \\
4-mer & $19(76)$ & $120.5(30.1)$ \\
4-mer & $18(72)$ & $128.1(32.2)$ \\
6--mer & $48(288)$ & $47.8(8.0)$ \\
\hline
\end{tabular}

a Values in parentheses are based on per TF-antigen basis. ${ }^{\mathrm{b}} \mathrm{N}, N$ '-bis(acrylamidoacetic acid)-based dendrimer series (not shown) (Baek, Rittenhouse-Olson, Roy, 2001). 


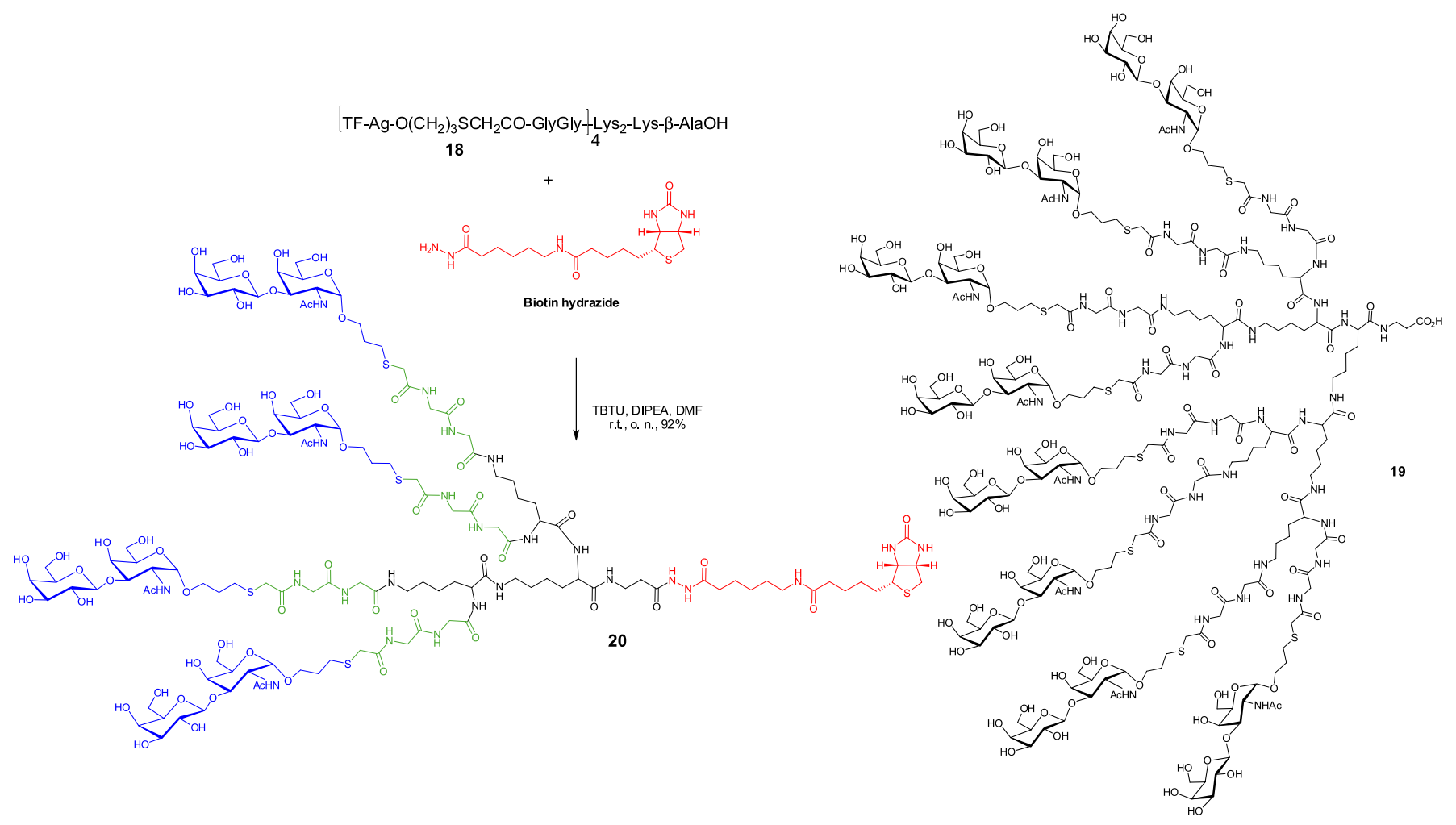

FIGURE 6 - Glycodendrimers built by solid-phase peptide synthesis using L-lysine as $\mathrm{A}_{2} \mathrm{~B}$ monomer (both $\alpha$ - and $\varepsilon$-amino groups are used simultaneously). The acid terminal, obtained from the Wang resin, was then coupled to a biotin hydrazide probe by amide coupling.

that a linear trimeric version of the $\mathrm{T}_{\mathrm{N}}$-antigen was more antigenic. Thus, analogous artificial vaccines composed of mono-, di- and- tri-meric $\mathrm{T}_{\mathrm{N}}$-antigens coupled to Ovine Serum Albumin (OSA), successfully provided antibody responses; although the trimeric antigen was more potent.

\section{2nd Generation TF-vaccine}

As mentioned, the Thomsen-Friedenreich TFantigen over expression on the cell surface of several types of tumor cells, contributes to cancer cell adhesion and severe metastasis to sites containing TF-Ag binding lectins (lungs, liver, lymph nodes). Our group showed that a highly specific immunoglobulin $\mathrm{IgG}_{3}$ monoclonal antibody (MAb) developed against the TF-Ag (JAA-F11) (Rittenhouse-Diakun et al., 1998) impeded TF-Ag binding to vascular endothelium, blocking a primary metastatic step and providing a survival advantage (Heimburg et al., 2006). In addition, in patients, even low levels of antibodies to TF-Ag seem to improve prognosis; thus, it is expected that vaccines generating antibodies toward TF-Ag would be clinically valuable. Unfortunately, vaccinations with protein conjugates of TACAs have induced clinically inadequate humoral immune responses.
Consequently, we tested the hypothesis that vaccinations with unique TF-Ag peptide mimics may generate more favorable immune responses to TF-carbohydrate epitopes on tumor cells, useful for active immunotherapy against relevant cancers. Peptide mimics of TF-Ag were thus selected by phage display biopanning (Figure 8) using JAA-F11 and rabbit anti-TF-Ag Ab and were analyzed in vitro to confirm TF-Ag peptide mimicry. Biopanning with mouse monoclonal $\mathrm{Ab}$ and rabbit $\mathrm{Ab}$ eluted with TF-Ag decreased the likelihood of nonspecific binding to $\mathrm{Ab}$. The percent recovery of binding phage increased with each round of biopanning. Final phage amplification and selection were performed with immunoprobing of titered phage followed by positive phage amplifications. Amplification of isolated phage was needed to obtain a sufficient amount of phage for subsequent experiments.

To identify the peptides that were able to mimic TFAg in immunoblot analysis and inhibition ELISA experiments, the selected phage were sequenced. Three phage clones returned the same sequence, providing evidence of a good mimicking sequence, and additional four different sequences were obtained. Two sequences of higher affinities are illustrated in Figure 9 and the phage that reacted 


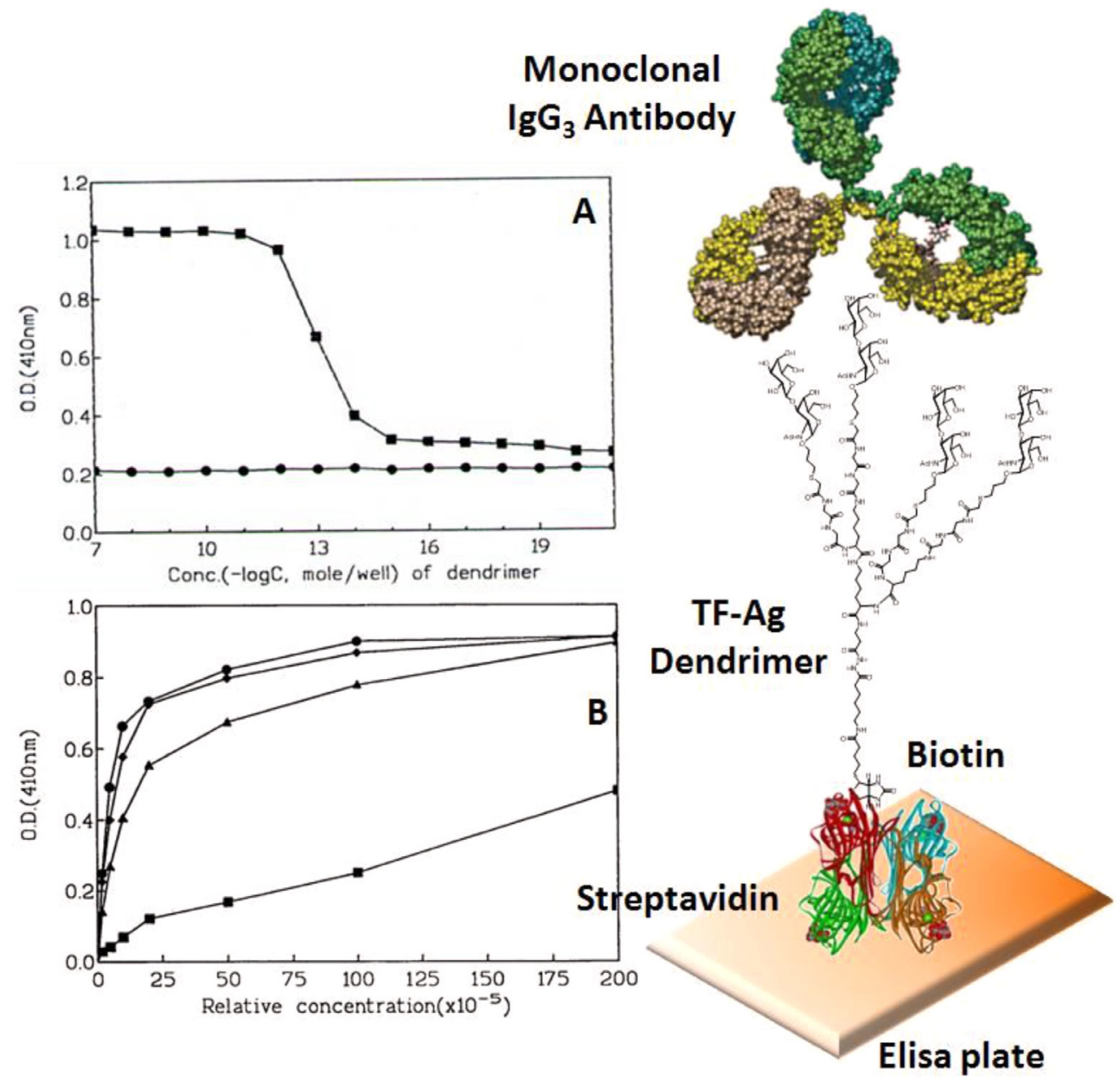

FIGURE 7 - Panel A: EIA using TF-Ag L-lysine tetramer (O) and biotin labeled T-Ag tetramer (ם) versus indirect mouse IgG capture by streptavidin coating. Peroxidase -labeled goat anti-mouse IgG and ABTS- $\mathrm{H}_{2} \mathrm{O}_{2}$ were used for detection. Panel B: EIA showing the coating properties of PAMAM-based T-Ag dendrimers (13-16) towards mouse IgG. Dendrimers: dimer ( $\mathbf{\square}$ ), tetramer $(\boldsymbol{\Delta})$, 16-mer $(\bullet)$, and 32-mer $(\boldsymbol{O})$. Peroxidase-labeled goat anti-mouse IgG and ABTS- $\mathrm{H}_{2} \mathrm{O}_{2}$ were used for detection.

best in the immunoblots and inhibition ELISAs using our IgG3 antibody (JAA-F11) and rabbit anti-TF-Ab was analyzed in vitro to further confirm TF-Ag peptide mimicry (Heimburg-Molinaro et al., 2009). Although both peptides 21 and 22 showed good affinity, fifteen-mer peptide mimic (21) (Figure 7) of the TF-Ag (H-I-H-G-W-K-S-P-L-S-S-LG-G-G) was initially chosen as the focus of further studies and chosen for dendrimer formation.

In vitro, TF-Ag peptide mimics bound to TF-Agspecific peanut agglutinin and blocked TF-Ag-mediated rolling and stable adhesion of cancer cells to vascular endothelium. In vivo, the immunization with TF-Agmimicking multiple antigenic peptides induced TF-Ag reactive $\mathrm{Ab}$ production. This novel active immunotherapy approach will hopefully decrease tumor burden in cancer patients by specifically targeting TF-Ag positive cancer cells and blocking metastasis. This represented, to the best of our knowledge, the first case of a dendritic peptidomimetics of a carbohydrate related antigen.

\section{Other related TF-antigen vaccines}

Another valuable alternative of the TF-antigen involving glycodendrimers with requisite immunochemical abilities has been recently disclosed (Shiao, Roy, 2012; Pri, 2013). Cumulated investigations pointed to the optimum structural requirements to construct successful glycoconjugate vaccines for cancer immunotherapy: 1) the presence of key TACAs as recognition motif and acting as B-cell epitope against which antibodies should be raised; 2) the presence of $\mathrm{CD}^{+} \mathrm{Th}$ cell peptide epitope and $\mathrm{CD}^{+} \mathrm{T}$ lymphocyte (CTL) to trigger both humoral and cytotoxic immunity, respectively; 3 ) the incorporation of non-immunogenic and non-toxic lipidic adjuvant 


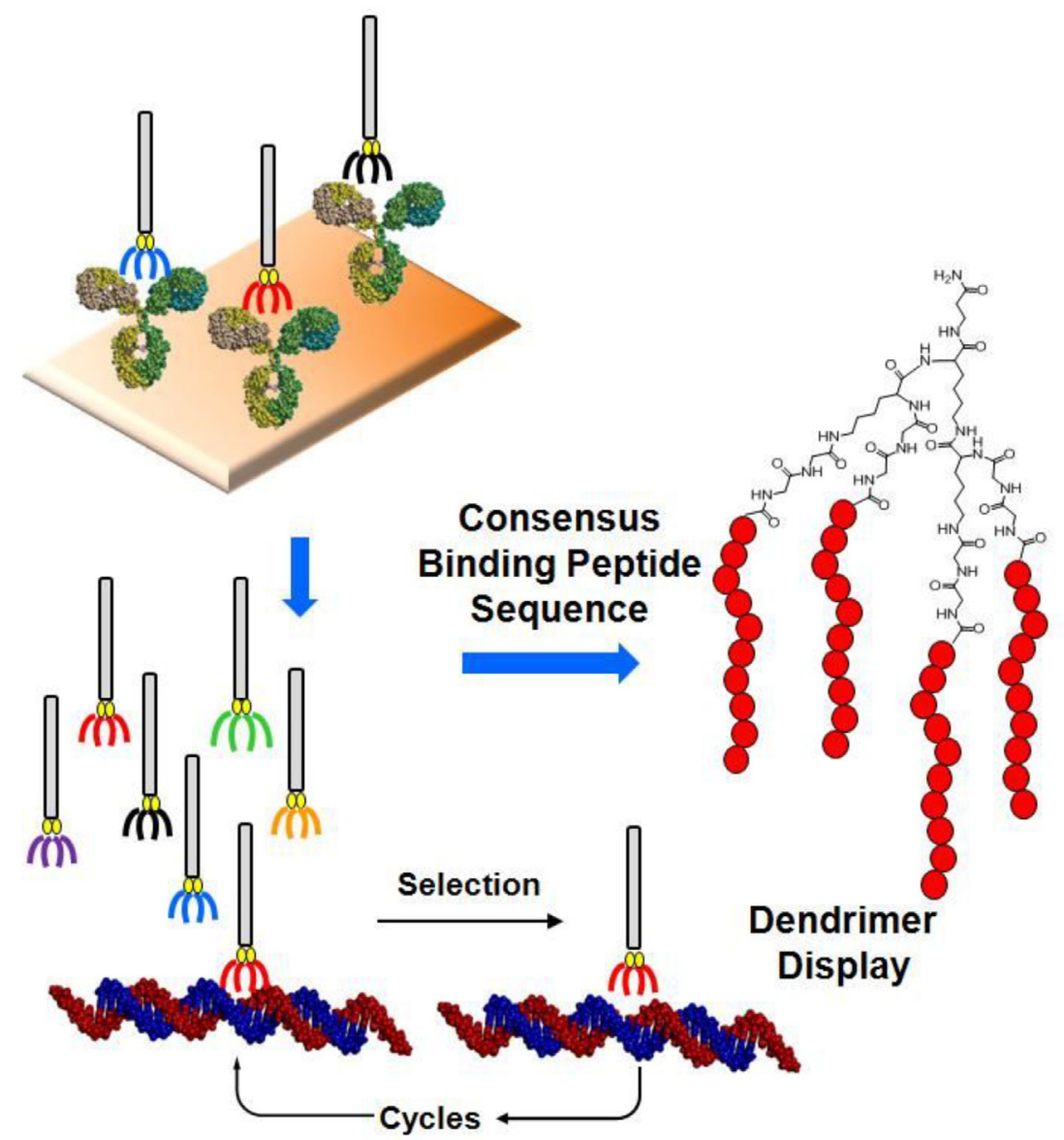

FIGURE 8 - Generation of phage display library used in biopanning and selection against two TF-Ag binding antibodies. Amplification and dendrimerization afforded a peptide vaccine that mimicked the carbohydrate epitope.

targeting the Toll-like receptors 2 (TLR-2) to provide self-adjuvanting property of the construct (Bettahi et al., 2009); and 4) the multivalency, either insured by the multi-task platform used to expose one or several different epitopes, or naturally generated through the propensity of lipid derivatives to form liposomes.

Dumy et al. capitalized on these cumulated observations toward the achievement of a fully synthetic fourcomponent antitumoral vaccine (24, Figure 10), built on a non-immunogenic cyclodecapeptide template (known as "RAFT" for "Regioselectively Addressable Functionalized Templates) (Dumy et al., 1995; Renaudet et al., 2008; Renaudet et al., 2010; Fiore et al., 2013). The optimized multiepitopic construct incorporated four copies of a $T_{N}$ antigen analogue as $\mathrm{B}$ cell epitope, the universal $\mathrm{CD}^{+}$ helper T-cell peptide from the type I-poliovirus protein together with a CD8 ${ }^{+} \mathrm{CTL}$ from ovalbumin $\left(\mathrm{OVA}_{257-264}\right.$ peptide SIINFEKL) to which was covalently added palmitic acid as lipid adjuvant. The peptidic epitopes were further combined to the scaffold through disulfide bridge to afford the desired vaccine nanoparticles composed of ovalbumin glyco-lipopeptide (OVA-GLP) 4 (Figure 10) (Bossu et al., 2011).

The study highlighted both B- and T-cells antigenicity as well as immunogenicity in vitro and in vivo assays. The authors first assessed the safety, the immunogenicity and the protective efficacy of $\mathbf{2 4}$ using MO5/BALB/c tumor mouse model. The investigations revealed the production of the tumor-specific antibodies (Abs) developed against the $\mathrm{T}_{\mathrm{N}}$ cluster displayed in the synthetic vaccine that efficiently recognized the native form of $\mathrm{T}_{\mathrm{N}}$ antigen presented on human tumor cells, as determined by flow cytometry between the immune serum IgG and the common breast cancer cell line MCF7. The efficient stimulation of T-cells was also observed, together with tumor regression and significant increase of survival in mice inoculated with MO5 carcinoma cells in both immunotherapeutic and immunoprophylactic settings. These promising results thus suggest that RAFT scaffold provides suitable tools for engineering other potent synthetic anticancer vaccines with optimized structural variations. 


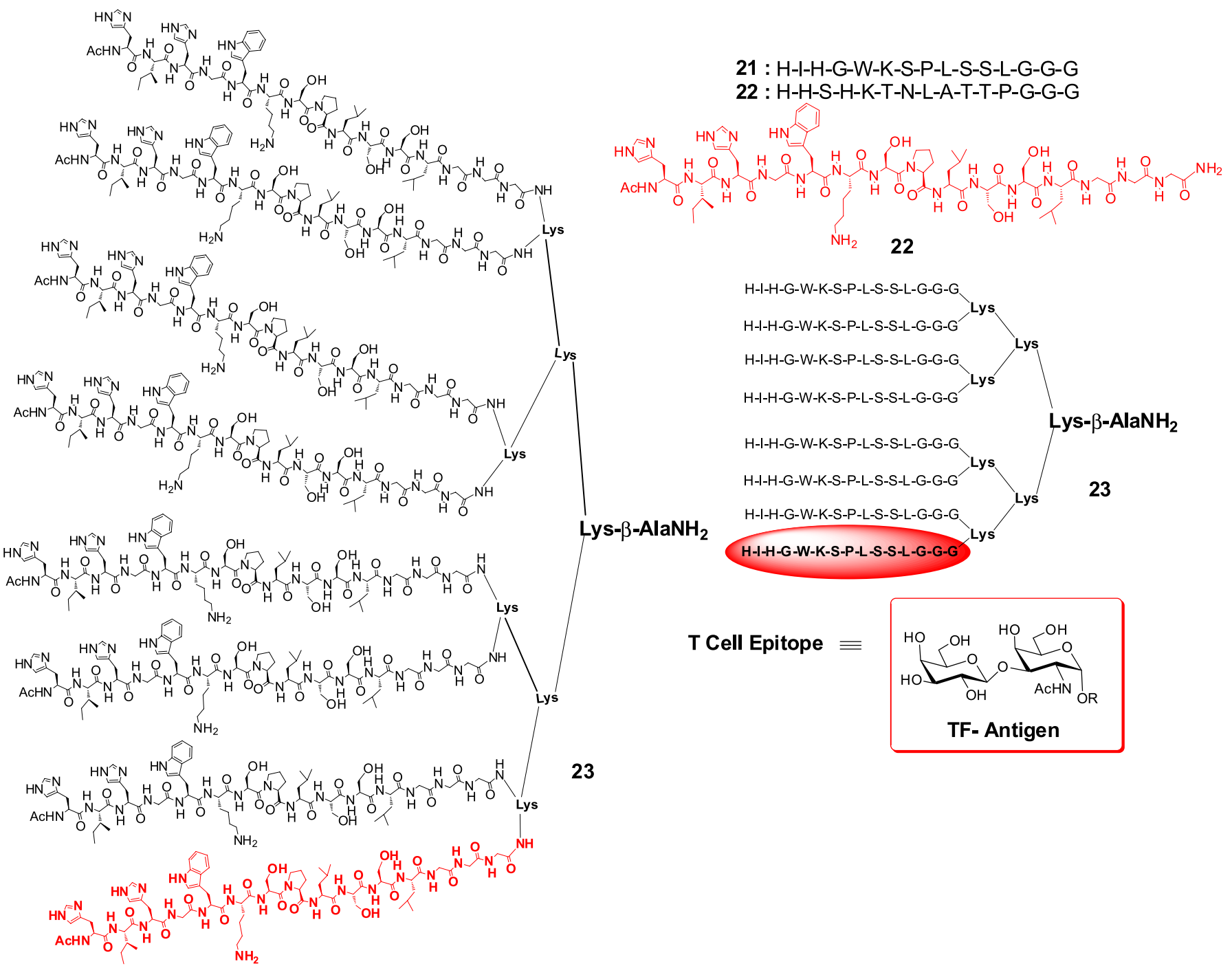

FIGURE 9 - Antigenic carbohydrate epitopes can be functionally replaced by peptide sequences. When multimerized into a dendritic molecular architecture, the resulting neoglycoconjugates can not only be recognized by anti-carbohydrate antibodies but can also act to trigger a successful immune response.

\section{Glycodendrimers as potential antimetastatic agents}

Several studies have demonstrated that interactions mediated by the cancer-associated Thomsen-Friedenreich glycoantigen (TF-Ag) and the carbohydrate-binding protein galectin-3 play an important role in several rate-limiting steps of cancer metastasis. An important finding (Glinsky et al., 1996; Almogren et al., 2012; Glinskii et al., 2012) demonstrated the ability of a synthetic small-molecularweight nontoxic carbohydrate-based TF-Ag mimic lactulose-L-leucine (Lac-L-Leu) (Glinsky et al., 1996) to inhibit metastasis in vitro and, ultimately, prostate cancer bone metastasis in vivo. Using an in vivo mouse model, based on intracardiac injection of human PC-3 prostate carcinoma cells stably expressing luciferase, the authors investigated the ability of Lac-L-Leu to impede the establishment and growth of bone metastasis. A number of assays were used to assess the effects of Lac-L-Leu on tumor cell adhesion to the endothelium. They reported that daily intraperitoneal administration of Lac-L-Leu resulted in a three-fold decrease in metastatic tumor burden compared with untreated control. Mechanistically, the effect of Lac-L-Leu, which binds and inhibits galectins by mimicking essential structural features of the TF-Ag, was associated with a dose-dependent inhibition of prostate cancer cell adhesion to bone marrow endothelium. They concluded that small molecular-weight carbohydrate-based compounds targeting $\beta$-galactoside-mediated interactions could provide valuable means for controlling and preventing metastatic prostate cancer spread to the skeleton. 


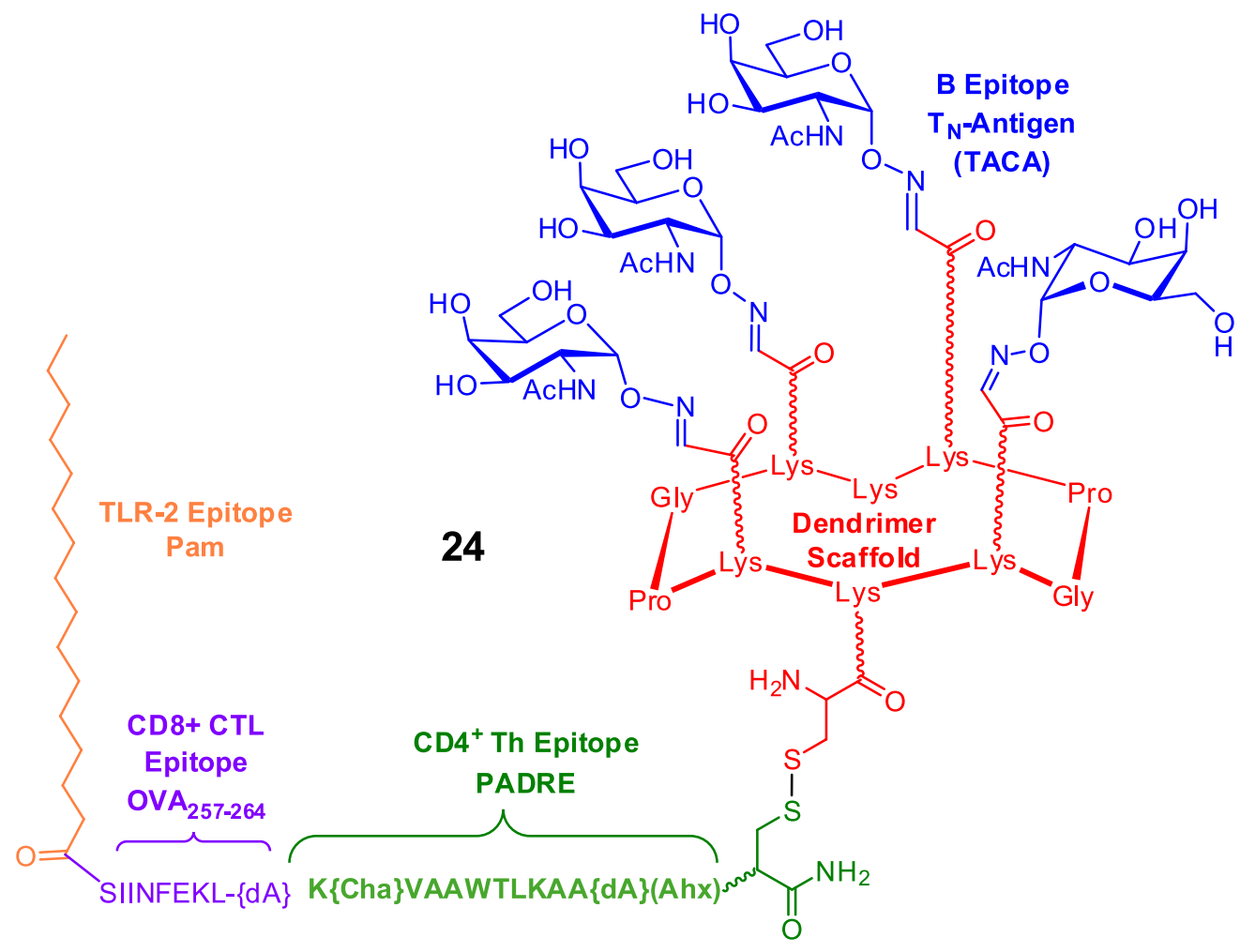

FIGURE 10 - Multicomponent TACA vaccine incorporating of the requisite elements to raise both humoral and cytotoxic immunity (Galan, Dumy, Renaudet, 2013).

Importantly, a few chemistry teams are actively involved in the search for potent galectin inhibitors (André et al., 1999; Giguère et al., 2006; Sirois, Giguère, Roy, 2006a; Giguère et al., 2006b; Giguère et al., 2008; André et al., 2010; Öberg, Leffler, Nilsson, 2011; Giguère et al., 2011; St-Pierre et al., 2012). Moreover, both small drug-like molecules 29-32 (Figure 11) together with glycodendrimers (Figure 5) (André et al., 1999) have shown that selected glycomimetics have the added potential to selectively target one of the fifteen human galectin family members. For instance compound $\mathbf{3 2}$ has a $\mathrm{K}_{\mathrm{d}}$ of $32 \mathrm{nM}$ against Galectin-3 (Van Hattum et al., 2013) The first demonstration that glycodendrimers could effectively show some level of selectivity has been shown with PAMAM-based lactose dendrimers illustrated in the red inset of Figure 5 (André et al., 1999). For instance, the lactose-PAMAM dendrimer in Figure 5 showed four fold enhancement of selectivity between Galectin-3 over Galectin-1. These results clearly illustrate the potential of using synthetic glycodendrimers as antimetastatic agents.

\section{Gold glyconanoparticles as vaccines}

Gold nanoparticles (NPs) are the most stable and studied among the metal based nano-clusters. Even though, a large number of methodologies are known for the preparation of gold NPs, the Burst technique or its variation are still the most popular for preparing monolayer of coated gold NPs, which is based on the high affinity of the thiol groups towards the gold atoms because of the soft character of both $\mathrm{Au}$ and $\mathrm{S}$ atoms (Brust et al., 1994). In this method, gold NPs are synthesized through reduction of gold salt $\left(\mathrm{HAuCl}_{4}\right)$ by $\mathrm{NaBH}_{4}$ in the presence of a thiol. Gold NPs coated with glycan monolayers have been studied extensively in various areas of biomedical research (Marradi, Martín-Lomas, Penadés, 2010; Marradi et al., 2010; Chang-Ming, 2011; Reichardt, MartínLomas, Penadés, 2013). Since the first report in 2001 (De La Fuente et al., 2001), gold glyconanoparticles (GNPs) received great attention among glycochemists.

Gold NPs have been used as multivalent and multifunctional platforms for tumor associated carbohydrate antigens in combination with suitable immunogenic carriers to develop carbohydrate based vaccines. The pioneering group of Penadés has been the first to identify gold NPs as potential scaffolds for vaccine preparation (De La Fuente et al., 2001). Accordingly, in an early report, hybrid glycoNPs have been synthesized by combining the Lewis ${ }^{\mathrm{Y}}$ (25) and the TF (26) oligosaccharides tumor markers, a peptide from tetanus toxoid (TT) as T-cell helper (27) 


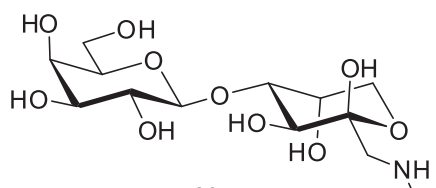

29<smiles>CC(C)C[C@H](N)C(=O)O</smiles>

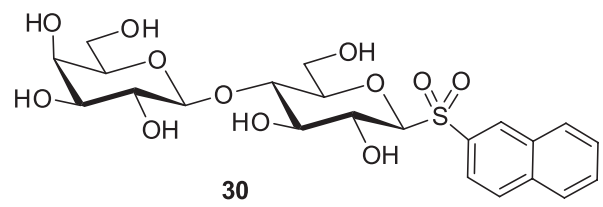

30

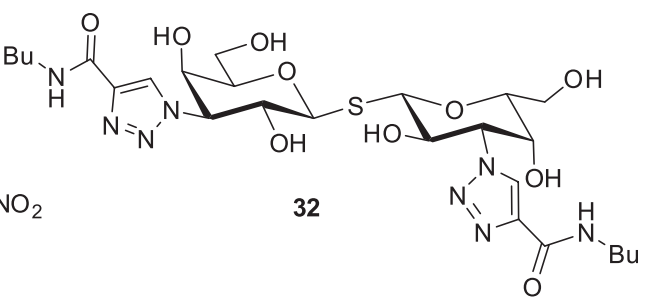

FIGURE 11 - Synthetic monovalent glycomimetics acting as selective galectin inhibitors.

and inert interspacing glucose moieties (28) to control the density of the above conjugates (Figure 12). Preliminary data showed that this hybrid glycoGNPs exhibited potent immunogenic activity.

In a more recent investigation, Barchi Jr. and co-workers reported another potential tumor vaccine construction prepared from QDs (Svarovsky, Barchi Jr., 2007) and gold NPs (Svarovsky, Szekely, Barchi Jr.
2005; Sundgren, Barchi Jr., 2008; Brinãs et al., 2012). Analogous gold glycoNPs have been loaded with three components that included: i) glycopeptides from Mucin-4, the Thomsen- Friedenreich antigen (TF-26) at various positions, ii) 28-residue peptide from complement derived protein $\mathrm{C} 3 \mathrm{~d}$ as a B-cell activating molecular adjuvant. In in vivo studies, sera from mice immunized with this glycoNPs, showed small but statistically significant antibody

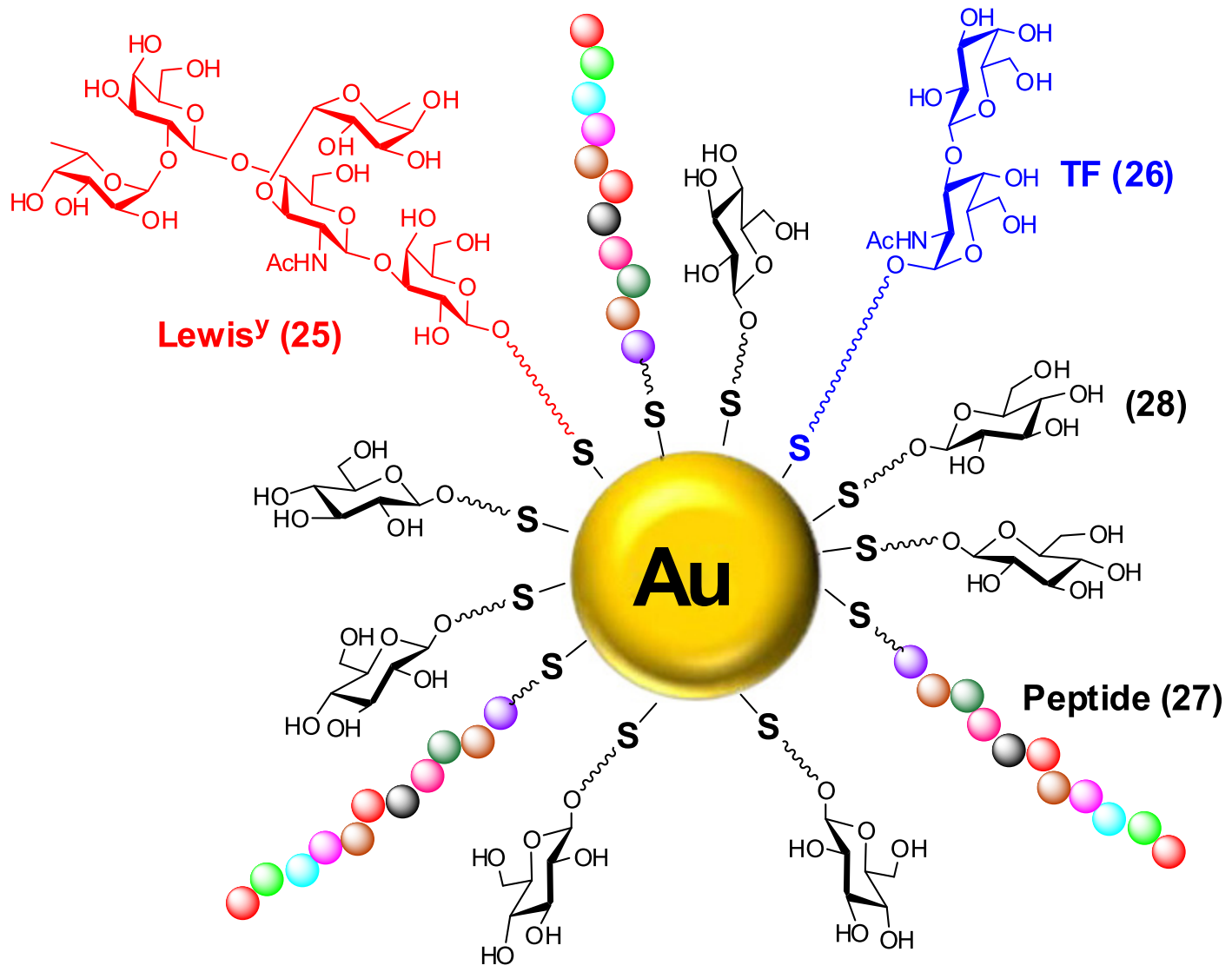

FIGURE 12 - Molecular structures of gold NPs based tumor vaccines exposing various sugar epitopes. 
responses (both $\mathrm{IgG}$ and $\mathrm{IgM}$ ) against the carbohydrate antigen. In addition to TF-functionalized glycoNPs, glycoconstructs from the peptides without the TF-antigen or linker alone also showed some immunogenicity. Among the TF functionalized glycoNPs, the mono functionalized conjugates showed the highest activity. The respective positioning of the TF-antigen along the peptide chain showed better selectivity toward IgG over IgM, whereas conjugates with the sugar at other positions exhibited similar selectivity for both IgG and IgM. Even though the results are still preliminary, the efficiency of glyco-NPs to acts as scaffolds for vaccine construction was successfully shown in both of the above applications.

\section{GLYCODENDRIMERS AS BACTERIAL ANTI- ADHESINS}

Infection by pathogens is generally initiated by crucial steps of recognition and adhesion on host epithelia surfaces. Very frequently, the strategy used by microorganisms involves the binding to host glycoconjugates by sugar-binding proteins, lectins, which are specific for the target tissue. The dependence between pathogen receptors and host glycans leads to the concept of "glycoecology" (Roy, 2003; Imberty, Chabre, Roy, 2008). In turn, the host immune system can also use lectins to identify and bind oligo- and polysaccharides on micro-organism surface, but in some cases the pathogens can reroute this process and use it for invasion. These infection strategies involve interactions characterized by their high specificity and most of the time by multivalency. The biochemical and structural data that have been accumulated recently offer chemists the possibility to interfere in the infection process through molecules that mimic the natural oligosaccharidic ligands and effectively compete for attachment sites. Different strategies using modified oligosaccharides, glycomimetics, oligomers, dendrimers, or polymers have been developed to enhance the overall affinity of carbohydrate ligands (Roy, 2003; Imberty, Chabre, Roy, 2008; Bernardi et al., 2013; Branson, Turnbull, 2013; Jiménez Blanco, Mellet, García Fernández, 2013).

Uropathogenic Escherichia coli infections, ultimately leading to cystitis and pyelonephritis, are initially mediated by the adhesion of the bacterial FimH to the transmembrane glycoprotein uroplakin-1a present at the surface of urothelial cells (Figure 13). The adhesion is based on the recognition and high avidity binding between the high-mannose glycans of the uroplakin and the FimH, a mannose-specific lectin located at the tip of type 1 fimbriae. It was found that synthetic multiantennary mannopyranosides glycodendrons, harboring triazole functionality at the anomeric position, were potent hemagglutination inhibitors of guinea pig erythrocytes and E. coli. A mannosylated dendrimer exposing up to sixteen sugar residues showed an HAI titer of $1 \mu \mathrm{M}$ and was thus 500 -fold more potent than the corresponding monovalent methyl $\alpha$-D-mannopyranoside (Figure 14). The synthesis of the glycodendrons involved highly efficient solid-phase synthesis of branched L-lysine scaffolds, diazo transfer reaction on the terminal amine residues, and [1,-3]-dipolar copper-catalyzed azide-alkyne

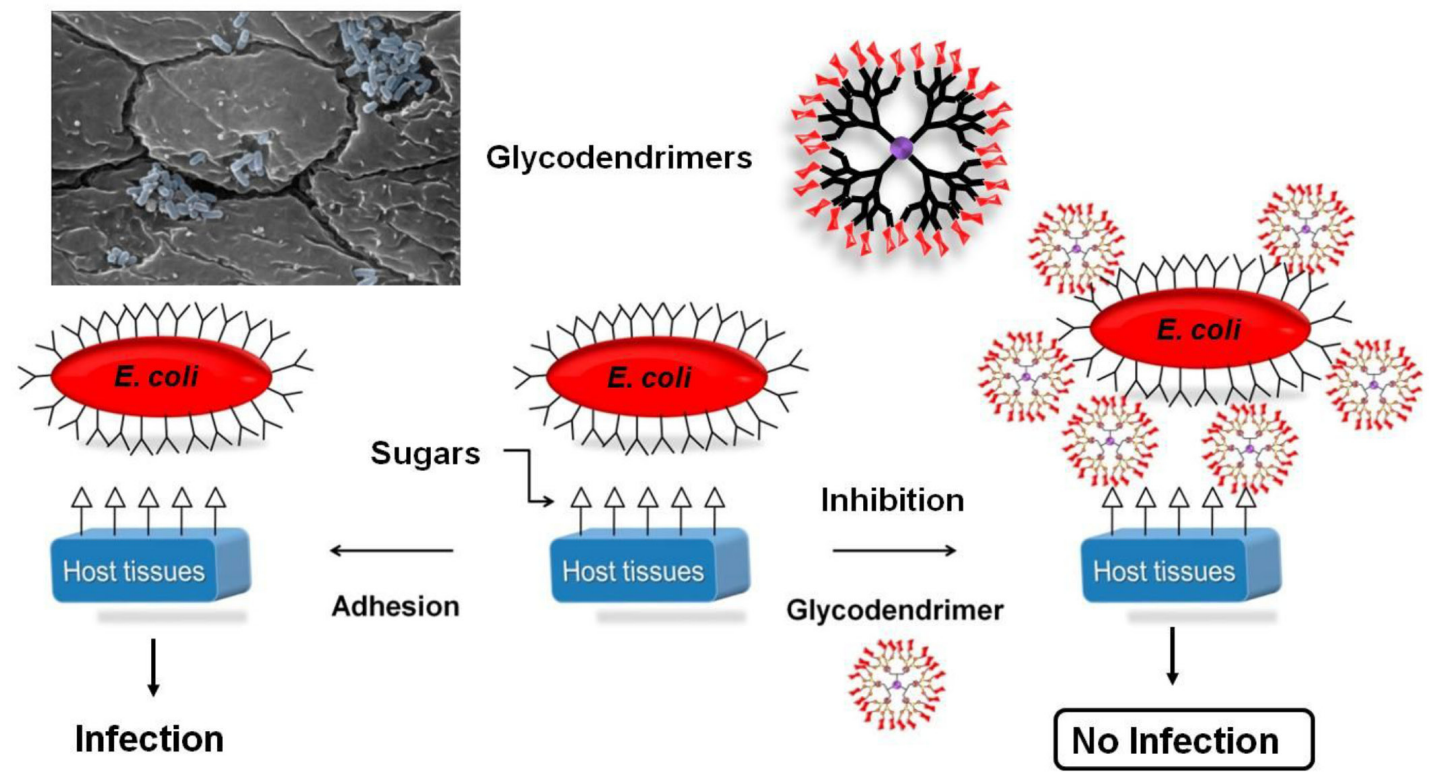

FIGURE 13 - Glycodendrimer inhibition strategy to block bacterial adhesion to host tissues. Given the usual low affinity of monovalent carbohydrate ligands toward bacterial lectins, multivalent ligand presentation on dendritic scaffolds leads to more potent candidates. 


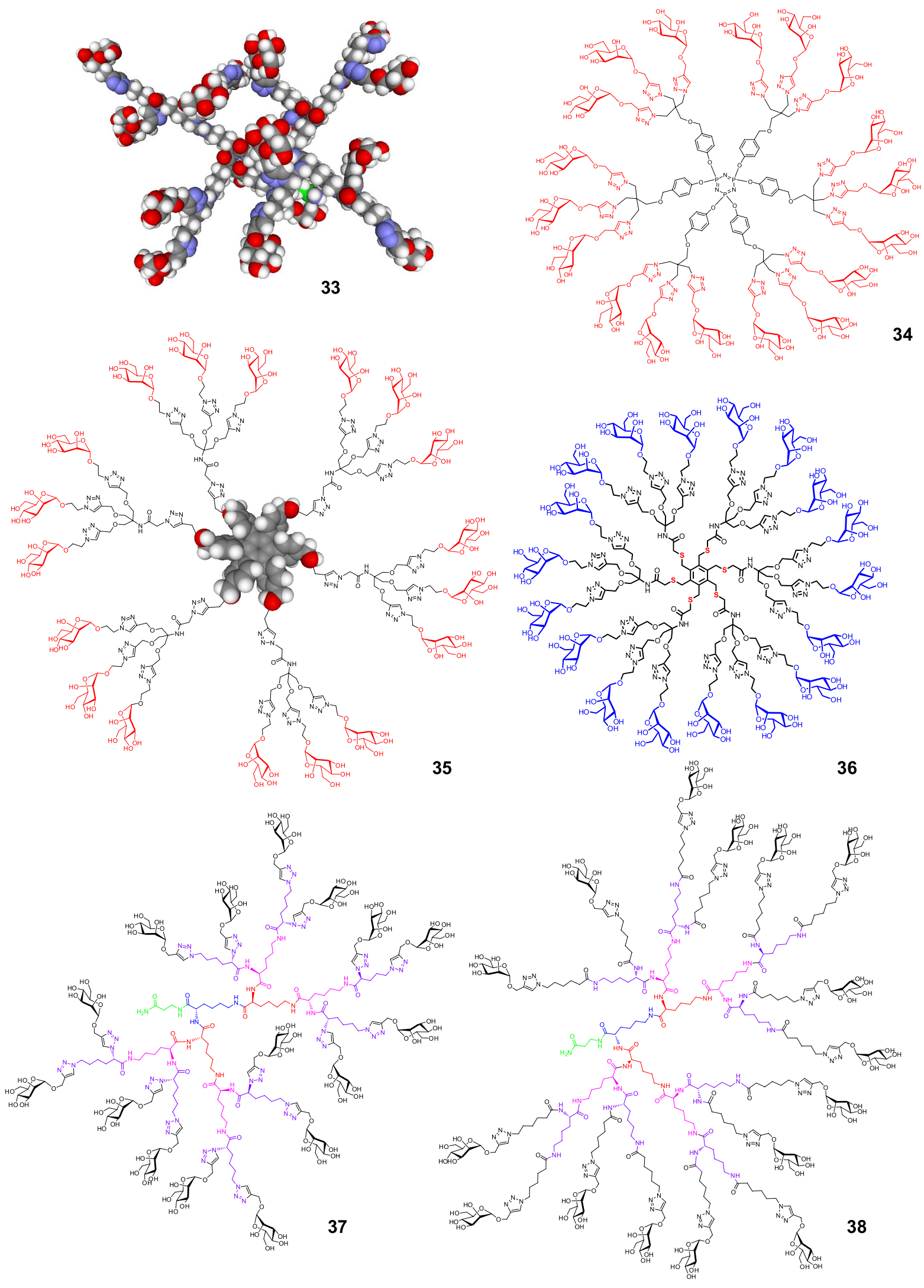

FIGURE 14 - Selected family members of glycodendrimers used against bacterial infections. Although they all harbour $\alpha$-Dmannopyrannoside ligands against uropathogenic $E$. coli FimH; analogous scaffolds were used with different saccharides moities recognized by other bacterial lectins. 
cycloaddition using propargyl $\alpha$-D-mannopyranoside (Papadopoulos, Shiao, Roy, 2012).

Several different classes of glycodendrimers harboring $\alpha$-D-mannopyranoside residues have been synthesized in the past from our groups (Figure 14) (Touaibia, Roy, 2007; Chabre, Roy, 2008) and from others (Röckendorf, Lindhorst, 2001; Hartmann, Lindhorst, 2011), including calyx[4]arenes (Sansone, Casnati, 2013), fullerene (Chabre, Roy, 2013), and cyclodextrins (Martínez, Mellet, Garcia Fernández, 2013). Figure 14 illustrates typical cases wherein L-lysine (Nagahori et al., 2002) was used as scaffold $(33,37,38)$, together with "Majoral-type" cyclotriphosphazene (34) (Touaibia, Roy, 2008), and aromatic scaffolds that included hexaphenylbenzene (35) (Chabre et al., 2011) and hexamethylthiobenzene (36) (Chabre et al., 2008).

The syntheses of two different families of mannosylated dendrons were efficiently accomplished using solid phase chemistry. Of particular interest was the observation that both the diazo transfer reaction and the [1,3]-dipolar copper-catalyzed cycloaddition could be accomplished during the solid-phase steps. The 15 step syntheses of the G(3) dendrons (37) were accomplished in an average of $16 \%$ overall yield. The second and extended family of mannodendrons (38), bearing an extra 6-aminohexanoic acid linker, showed better inhibitory potencies in inhibition of hemagglutination assays of guinea pig erythrocytes and fimbriated E. coli. The best candidate 38, with an HAI titer of $1 \mu \mathrm{M}$, showed a 32-fold better binding affinity when corrected on a per mannoside residue. This value compares favorably well with the ones recently published using fullerene (Durka et al., 2011) or pentaerythritol (Gouin et al., 2009) scaffolds. However, a linear heptameric mannocluster built on sugar scaffolds and having a more hydrophobic heptyl aglycon showed better HAI titers than the one reported herein (Almant et al., 2011).

We also demonstrated (unpublished data) that some of the above mannosylated glycodendrimers were capable of inhibiting the binding of fluorescently-labelled plant lectin such as ConA from Canavalia ensiformis to brain cancer line U87 in a dose dependent manner (Figure 15). While monosaccharide methyl $\alpha$-D-mannopyrannoside was unable to inhibit ConA from binding to U87, glycodendrimer 37 could almost completely abolish the lectin from binding.
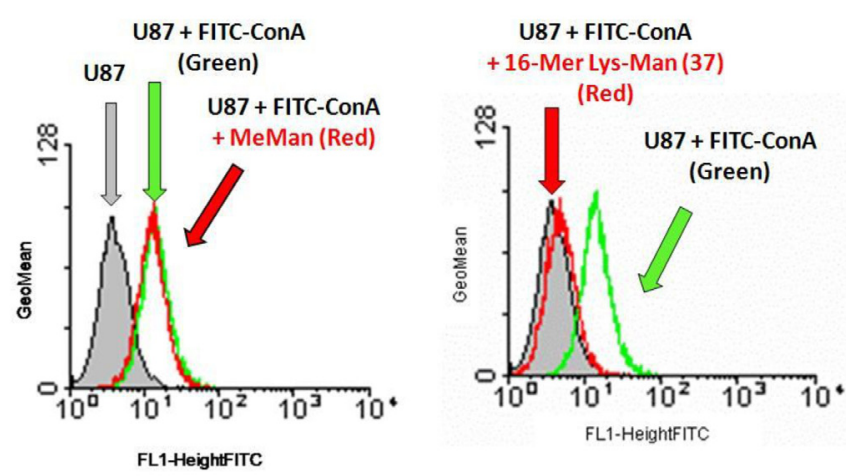

FIGURE 15 - Inhibition of binding of fluorecently-labelled plant lectin ConA to glyoblastomas U87 by mannodendrimer 37 .

\section{GOLD AND UPCONVERTING LANTHANIDE NANOPARTICLES}

A novel and simple approach on which nanometersize $(<2 \mathrm{~nm})$, water soluble glycodendrimer coated gold nanoparticles (Au-man) were reported that allowed the detection of protein-carbohydrate interactions based on surface energy transfer process (SET) (Figure 16)

TABLE II - Relative inhibitory properties of the two series of mannosylated glycodendrimers measured by the hemagglutination titer (HAI) against guinea pig erythrocytes and fimbriated uropathogenic E. coli BW25113

\begin{tabular}{lcccc}
\hline Compound & $\begin{array}{c}\text { Nb surface groups } \\
\text { (Valency) }\end{array}$ & HAI titer $(\mu \mathbf{M})$ & Relative potency & $\begin{array}{c}\text { Relative potency/ } \\
\text { Mannoside }\end{array}$ \\
\hline Me $\alpha$ D-Man & 1 & 500 & 1 & 1 \\
$\mathrm{G}(0)^{\mathrm{a}}$ & 2 & 78.1 & 6 & 3 \\
$\mathrm{G}(1)^{\mathrm{a}}$ & 4 & 62.5 & 8 & 2 \\
$\mathrm{G}(2)^{\mathrm{a}}$ & 8 & 15.6 & 32 & 4 \\
$\mathbf{3 7} \mathrm{G}(3)$ & 16 & 2.0 & 256 & 16 \\
$\mathrm{G}(1)^{\mathrm{b}}$ & 4 & 62.5 & 8 & 2 \\
$\mathrm{G}(2)^{\mathrm{b}}$ & 8 & 7.8 & 64 & 8 \\
$\mathbf{3 8} \mathrm{G}(3)$ & 16 & 1.0 & 512 & 32 \\
\hline
\end{tabular}

a Structures without spacer in the $\alpha$-Lys position (not shown). ${ }^{\text {b }}$ Structures with spacer in the $\alpha$-Lys position (not shown). 
(Bodgan, Roy, Morin, 2012). The Gold-NPs were constructed from poly(amidoamine) PAMAM generation G0 dendrimers scaffolded on cystamine using the borohydride reduction of a gold salt (Brust et al., 1994).

The amine-exposed Gold-NPs were then treated with $p$-isothiocyanatophenyl $\alpha$-D-mannopyranoside. This sensitive SET sensing approach enables quantitative analysis of the binding constant of a mannose-binding protein, lectin Concanavalin A (Con A) labelled with a fluorophore to a sensing $\mathrm{Au}$-Mannoside in aqueous samples. Competitive binding and inhibition assays were done to investigate the SET efficiency. The binding constant of Con A to $\mathrm{Au}-\mathrm{Man}$ interactions of $(5.6 \pm 0.1) \times 10^{6} \mathrm{M}^{-1}$ was shown to be 100 -times higher than the binding constant values obtained in the interactions with the glycodendrimer G2 alone. The simple modification of the gold nanoparticles with glycodendrimers provided a convenient method to obtain biocompatible and selective carbohydrate-based SET probes for protein biorecognition.

It was also demonstrated that the efficiency of SET decreases when mannan, a mannose polysaccharide, blocked efficiently the receptors of lectin as only $10 \%$ of

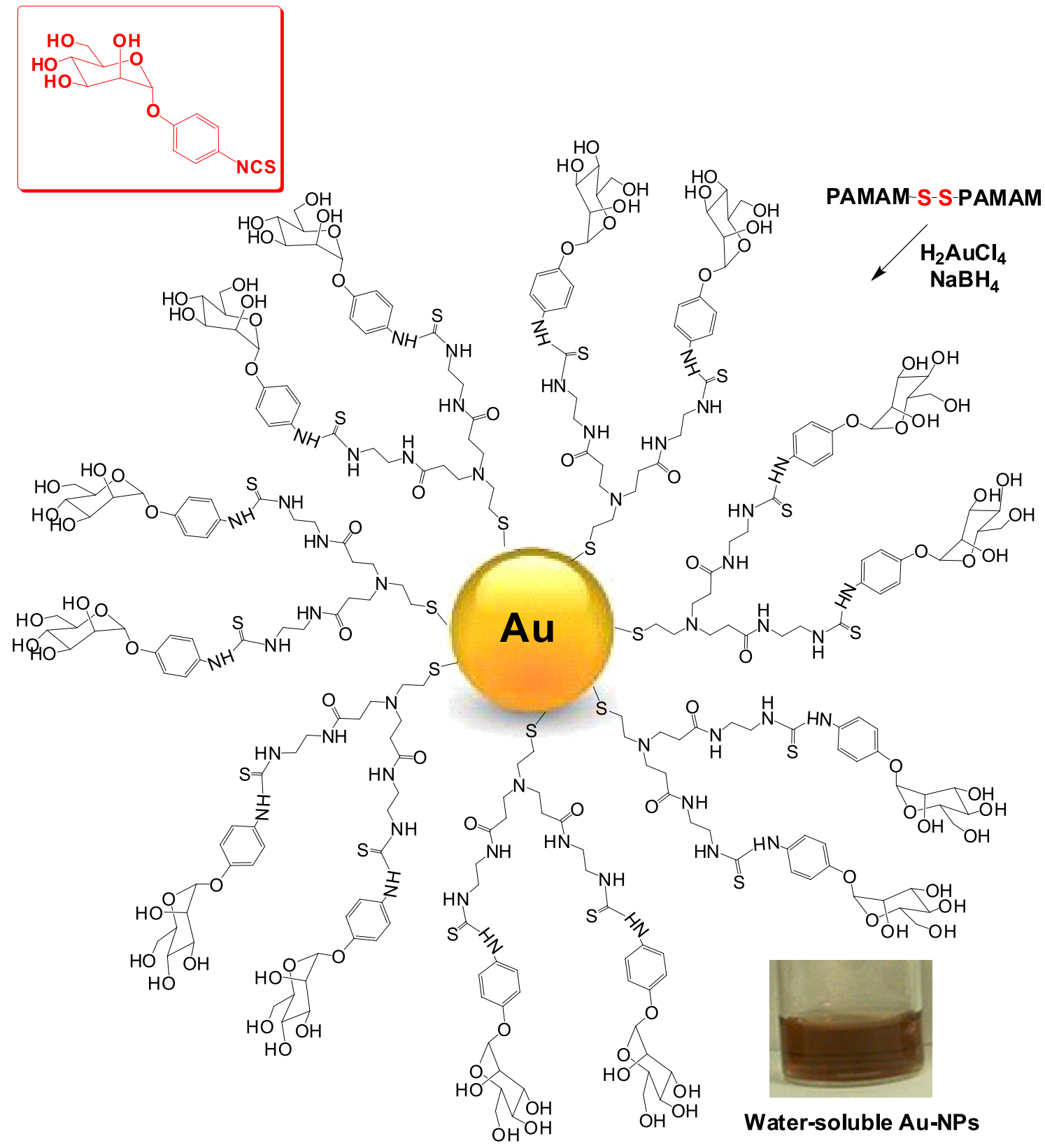

FIGURE 16 - Water-soluble Gold-NPs constructed with surrounding PAMAM dendrimers to which were linked thioureas ending with mannopyranoside derivative. 


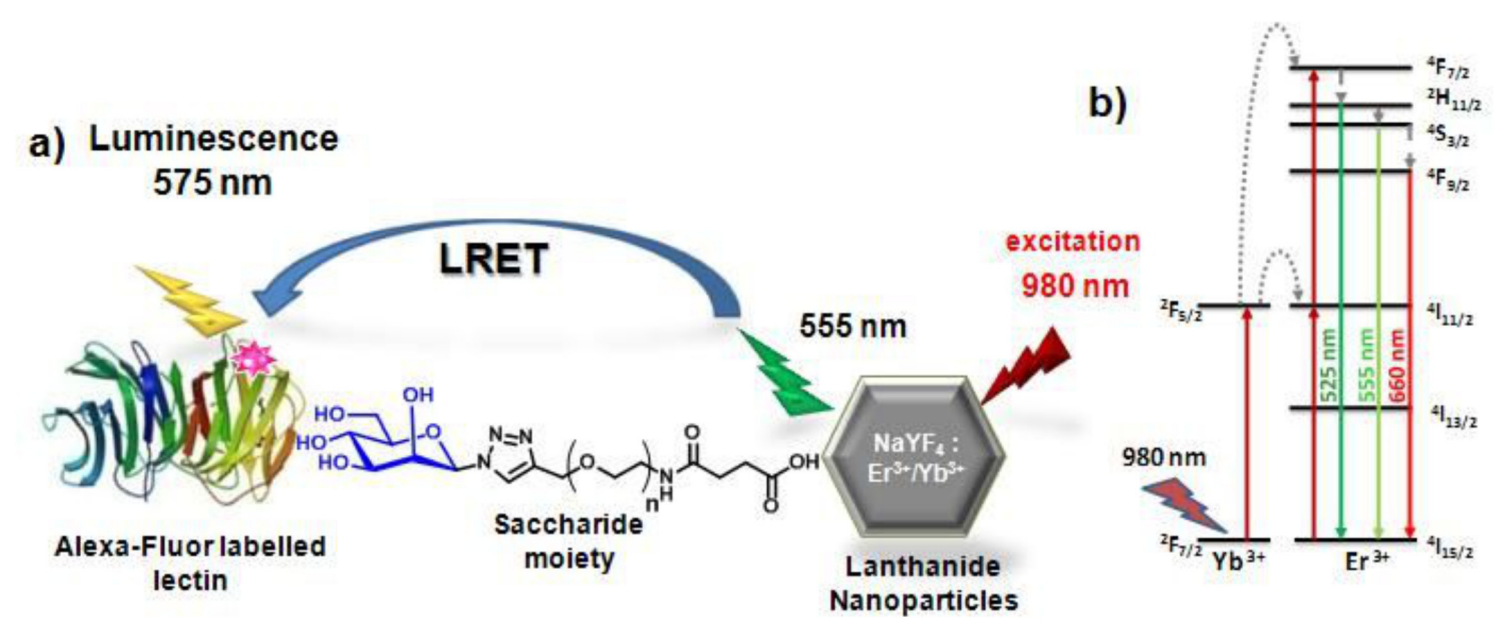

FIGURE 17 - Upconverting lanthanide nanoparticles coated with $\alpha$-D-mannopyranoside residues anchored to PAMAM dendrimers via thiourea linkages.

fluorescence of FITC-Con A was decreased after addition of Au-Man. In addition, the efficiency of SET decreases in the presence of an inhibitor as the fluorescence of FITC-Con A in complex with Au-Man was recovered up to $80 \%$ after addition of the monomeric $\alpha$-D-mannose used in molar concentration. For further application, this novel SET sensing glycodendrimer coated gold nanoparticles could be used in bacteria and cancer detection as well as in protein microarray assays.

Interestingly, these mannoside-bound Gold-NPs could be selectively precipitated with their cognate lectins while they did not agglutinate in the presence of other unrelated lectins such as wheat germ agglutinin (WGA). In addition, the precipitate could be recovered for protein purifications and the Gold pellets could be recovered with large concentration of D-mannose but not with Dgalactose by competive inhibition. More surprisingly, it was found that the mannose-NPs could provoke the clustering of piliated $E$. coli, thus demonstrating their potential usefulness as biosensors.

Similarly, upconverting lanthanide (Ln3+)-doped nanoparticles conjugated with glycodendrimers capable of recognizing lectins based on luminescence resonance energy transfer (LRET) were also developed in our group (Bogdan et al., 2010). Poly(amidoamine) (PAMAM) dendrimers were adsorbed on the surface of $\mathrm{NaGdF}_{4}: \mathrm{Er}_{3}{ }_{3}$, $\mathrm{Yb}_{3}{ }^{+}$upconverting nanoparticles (LnNPs) via direct ligand-exchange followed by efficient thiourea linkage formation between the amine surface and $p$-isothiocyanatophenyl $\alpha$-D-mannopyranoside for covalent carbohydrate derivatization. The resulting water dispersible and biocompatible mannose coated PAMAM-LnNPs of $25 \mathrm{~nm}$ size were used to recognize a lectin, Concanavalin A (a mannose binding protein) conjugated with tetramethylrho- damine (RITC-Con A) via LRET from the upconverting mannose-coated PAMAM-LnNPs, which act as energy donors to the RITC-labeled lectin molecules serving as energy acceptors. The energy transfer phenomenon from the mannose-coated PAMAM-LnNPs, following $980 \mathrm{~nm}$ excitation, to the RITC-Con A was observed with increasing emissions at $585 \mathrm{~nm}$, as the concentration of lectin increases. These novel carbohydrate-coated LnNPs prove to be a novel tool to monitor the binding interaction with lectins in aqueous samples (Figure 17).

\section{CONCLUSION}

This review has unequivocally demonstrated that, when key carbohydrate residues are grafted onto nanoparticles of varied genesis, they can successfully contribute to many advantages toward biomedical applications. The mixed expertise in nanosciences, glycochemistry and glycobiology, coupled to expert knowledge in photophysics, has permitted to push the frontiers of nanomaterials closer to nanomedicine. Several examples have also been used to demonstrate that once glycosylated, several hitherto toxic nanoparticles can acquire cellular safety. The rapidly growing interest for this moving field is providing a wonderful tool box wherein scientists' creativity will constitute the only limitation. Better insights into multivalent carbohydrate-protein interactions will further our appreciation of the "glycocodes" complexity which should undoubtedly allow more precisely the targeting of drugs and genes delivery.

If state of the art synthetic organic methodologies are combined to carbohydrate chemistry, it appears straightforwardly that the next generation of glyconanoparticles will exemplify even more complex saccharide structures that will likely also include glycomimetics. This last statement 
simply follows the actual trends in improved carbohydrate ligands and inhibitors design that encompasses more hydrolytically stable analogues, most of which successfully demonstrating much simpler hybrid glyco-pharmacophore structures that better mimics newer drug conceptions.

\section{ACKNOWLEDGMENTS}

The generous financial support by a Canadian Research Chair (CRC) in Therapeutic Chemistry from the Natural Sciences and Engineering Research Council of Canada is gratefully acknowledged.

\section{REFERENCES}

ALMANT, M.; MOREAU, V.; KOVENSKY, J.; BOUCKAERT, J.; GOUIN, S.G. Clustering of Escherichia coli type-1 fimbrial adhesins by using multimeric heptyl $\alpha-D-$ mannoside probes with a carbohydrate core. Chem. Eur. J., v.17, p.10029-10038, 2011.

ALMOGREN,A.;ABDULLAH, J.; GHAPURE, K.; FERGUSON, K.; GLINSKY, V.V.; RITTENHOUSE-OLSON, K. Anti-Thomsen-Friedenreich-Ag (anti-TF-Ag) potential for cancer therapy. Front Biosci., v.S4, p.840-863, 2012.

ANDRÉ, S.; ORTEGA, P.J.C.; PEREZ, M.A.; ROY, R.; GABIUS, H.-J. Lactose-containing starburst dendrimers: influence of dendrimer generation and binding-site orientation of receptors (plant/animal lectins and immunoglobulins) on binding properties. Glycobiology, v.9, p.1253-1261, 1999.

ANDRÉ, S.; GIGUERE, D.; DAM, T.K.; BREWER, F.; GABIUS, H.-J.; ROY, R. Synthesis and screening of a small glyco-mimetic library for inhibitory activity on medically relevant galactoside-specific lectins in assays of increasing bio-relevance. New J. Chem., v.34, p.2229-2240, 2010.

AVCI, F.Y.; KASPER, D.L. How bacterial carbohydrates influence the adaptive immune system. Annu. Rev. Immunol., v.28, p.107-130, 2010.

BAEK, M.-G.; RITTENHOUSE-OLSON, K.; ROY, R. Synthesis and antibody binding properties of glycodendrimers bearing the tumor related T-antigen. Chem. Commun., p.257-258, 2001.

BAEK, M.-G.; ROY, R. Design and synthesis of water-soluble glycopolymers bearing breast tumor marker and enhanced lipophilicity for solid-phase assays. Biomacromolecules, v.1, p.768-770, 2000.
BAEK, M.-G.; ROY, R. Glycodendrimers: novel glycotope isosteres unmasking sugar coding. Case study with T-antigen markers from breast cancer MUC1 glycoprotein. Rev. Mol. Biotechnol., v.90, p.291-309, 2002a.

BAEK, M.-G.; ROY, R. Relative lectin binding properties of T-antigen-containing glycopolymers: copolymerization of $N$-acryloylated T-antigen monomer vs. graft conjugation of aminated T-antigen ligands onto poly $(N$ acryloxysuccinimide). Macromol. Biosci., v.1, p.305-311, 2001a.

BAEK, M.-G.; ROY, R. Simultaneous binding of mouse monoclonal antibody and streptavidin to hetero-bifunctional dendritic L-lysine core bearing T-antigen tumor marker and biotin. Bioorg. Med. Chem., v.9, p.3005-3011, 2001 b.

BAEK, M.-G.; ROY, R. Synthesis and protein binding properties of T-antigen containing glycoPAMAM dendrimers. Bioorg. Med. Chem., v.10, p.11-17, 2002b.

BAST JR, R.C.; BADGWELL, D.; LU, Z.; MARQUEZ, R.; ROSEN, D.; LIU, J.; BAGGERLY, K.A.; ATKINSON, E.N.; SKATES, S.; ZHANG, Z.; LOKSHIN, A.; MENON, U.; JACOBS, I.; LU, K. New tumor markers: CA125 and beyond. Int. J. Gynecol. Cancer, v.15, s3, p.274-281, 2005.

BECKER, T.; DZIADEK, S.; WITTROCK, S.; KUNZ, H. Synthetic glycopeptides from the mucin family as potential tools in cancer immunotherapy. Curr. Cancer Drug Targets, v.6, p.491-517, 2006.

BERNARDI, A.; JIMÉNEZ-BARBERO, J.; CASNATI, A.; DE CASTRO, C.; DABRE, T.; FIESCHI, F.; FINNE, J.; FUNKEN, H.; JAEGER, K.-E.; LAHMANN, M.; LINDHORST, T.K.; MARRADI, M.; MESSNER, P.; MOLINARO, A.; MURPHY, P.V.; NATIVI, C.; OSCARSON, S.; PENADÉS, S.; PERI, F.; PIETERS, R.J.; RENAUDET, O.; REYMOND, J.-L.; RICHICHI, B.; ROJO, J.; SANSONE, F.; SCHÄFFER, C.; TURNBULL, W.B.; VELASCO-TORRIJOS, T.; VIDAL, S.; VICENTE, S.; WENNEKES, T.; ZUILHOF, H.; IMBERTY, A. Multivalent glycoconjugates as anti-pathogenic agents. Chem. Soc. Rev., v.42, p.4709-4727, 2013.

BETTAHI, I.; DASGUPTA, G.; RENAUDET, O.; CHENTOUFI, A.A.; ZHANG, X.; CARPENTER, D.; YOON, S.; DUMY, P.; BENMOHAMED, L. Antitumor activity of a selfadjuvanting glyco-lipopeptide vaccine bearing B cell, CD4+ and CD8+ T cell epitopes. Cancer Immunol. Immunother., v.58, p.187-200, 2009. 
BODGAN, N.; ROY, R.; MORIN, M. Glycodendrimer coated gold nanoparticles for proteins detection based on surface energy transfer process. RSC Advances, v.2, p.985-991, 2012.

BOGDAN, N.; VETRONE, F.; ROY, R.; CAPOBIANCO, J.A. Carbohydrate-coated lanthanide-doped upconverting nanoparticles for lectin recognition. J. Mater. Chem., v.20, p.7543-7550, 2010.

BOSSU, I.; ŠULC, M.; KŘENEK, K.; DUFOUR, E.; GARCIA, J.; BERTHET, N.; DUMY, P.; KŘEN, V.; RENAUDET, O. Dendri-RAFTs: a second generation of cyclopeptide-based glycoclusters. Org. Biomol. Chem., v.9, p.1948-1959, 2011.

BRINÃS, R.P.; SUNDGREN, A.; SAHOO, P.; MOREY, S.; RITTENHOUSE-OLSON, K.; WILDING, G.E.; DENG, W.; BARCHI JR., J.J. Design and synthesis of multifunctional gold nanoparticles bearing tumorassociated glycopeptide antigens as potential cancer vaccines. Bioconjugate Chem., v.23, p.1513-1523, 2012.

BRANSON, T.R.; TURNBULL, W.B. Bacterial toxin inhibitors based on multivalent scaffolds. Chem. Soc. Rev., v.42, p.4613-4622, 2013.

BRUST, M.; WALKER, M.; BETHELL, D.; SCHIFFRIN, D.J; WHYMAN, R. Synthesis of thiol-derivatized gold nanoparticles in a two-phase liquid-liquid system. J. Chem. Soc., Chem. Commun., n.7, p.801-802, 1994.

CHABRE, Y.M.; BRISEBOIS, P.P.; ABBASSI, L.; KERR, S.C.; FAHY, J.V.; MARCOTTE, I.; ROY, R. Hexaphenylbenzene as a rigid template for the straighforward syntheses of "StarShaped" glycodendrimers. J. Org. Chem., v.76, p.724-727, 2011.

CHABRE, Y.M.; CONTINO-PÉPIN, C.; PLACIDE, V.; SHIAO, T.C.; ROY, R. Expeditive synthesis of glycodendrimer scaffolds based on versatile TRIS and mannoside derivatives. J. Org. Chem., v.73, p.5602-5605, 2008.

CHABRE, Y.M.; ROY, R. Dendrimer-coated carbohydrates as drug delivery trojan horses in glycosciences. In: CHENG, Y. (Ed). Dendrimer-based drug delivery systems: from theory to practice. Weinheim: Wiley-VCH, 2012. chap.11, p.407-438.

CHABRE, Y.M.; ROY, R. Design and creativity in synthesis of multivalent neoglycoconjugates. Adv. Carbohydr. Chem. Biochem., v.63, p.165-393, 2010.
CHABRE, Y.M.; ROY, R. Multivalent glycoconjugate syntheses and applications using aromatic scaffolds. Chem. Soc. Rev., v.42, p.4657-4708, 2013.

CHABRE, Y.M.; ROY, R. Recent trends in glycodendrimer syntheses and applications. Curr. Top. Med. Chem., v.8, p.1237-1285, 2008.

CHABRE, Y.M.; ROY, R. The chemist's way to prepare multivalency. In: GABIUS, H.J. (Ed). The sugar code: fundamentals of glycosciences. Weinheim: Wiley-VCH, 2009. chap.4, p.53-70.

CHANG-MING, D. Glyconanoparticles for biomedical applications. Comb. Chem. High Throughput Screening, v.14, p.173-181, 2011.

CIPOLLA, L.; PERI, F.; AIROLDI, C. Glycoconjugates in cancer therapy. Anticancer Agents Med. Chem., v.8, n.1, p.92-121, 2008.

COBB, B.A.; KASPER, D.L. Commentary: coming of age: carbohydrates and immunity. Eur. J. Immunol., v.35, p.352356, 2005.

DANISHEFSKY, S.J.; ALLEN, J.R. From the laboratory to the clinic: a retrospective on fully synthetic carbohydratebased anticancer vaccines. Angew. Chem. Int. Ed., v.39, p.836-863, 2000.

DE LA FUENTE, J.M.; BARRIENTOS, A.G.; ROJAS, T.C.; ROJO, J.; CANADA, J.; FERNANDEZ, A.; PENADÉS, $\mathrm{S}$. Gold glyconanoparticles as water-soluble polyvalent models to study carbohydrate interactions. Angew. Chem. Int. Ed., v.40, p.2258-2261, 2001.

DE LA FUENTE, J.M.; PENADÉS, S. Glyconanoparticles: types, synthesis and applications in glycoscience, biomedicine and material science. Biochim. Biophys. Acta, v.1760, p.636-651, 2006.

DE SILVA, R.A.; WANG, Q.; CHIDLEY, T.; APPULAGE, D.K.; ANDREANA, P.R. Immunological response from an entirely carbohydrate antigen: Design of synthetic vaccines based on Tn-PS A1 conjugates. J. Am. Chem. Soc., v.131, p.9622-9623, 2009.

DOANE, T.L.; BURDA, C. The unique role of nanoparticles in nanomedicine: imaging, drug delivery and therapy. Chem. Soc. Rev., v.41, p.2885-2911, 2012. 
DONOVAN, R.S.; ROB, S.; DATTI, A.; BAEK, M.-G.; WU, Q.; SAS, I.J.; KORCZAK, B.; BERGER, E.G.; ROY, R.; DENNIS, J.W. A solid-phase glycosyltransferase assay for high-throughput screening in drug discovery research. Glycoconjugate J., v.16, p.607-615, 2000.

DUMY, P.; EGGLESTON, I.M.; CERVIGNI, S.; SILA, U.; SUN, X.; MUTTER, M. A convenient synthesis of cyclic peptides as regioselectively addressable functionalized templates (RAFT). Tetrahedron Lett., v.36, p.1255-1258, 1995.

DURKA, M.; BUFFET, K.; IEHL, J.; HOLLER, M.; NIERENGARTEN, J.-F.; TAGANNA, J.; BOUCKAERT, J.; VICENTE, S.P. The functional valency of dodecamannosylated fullerenes with Escherichia coli FimH-towards novel bacterial antiadhesives. Chem. Commun., v.47, p.1321-1323, 2011.

EL-BOUBBOU, K.; HUANG, X. Glyco-nanomaterials: Translating insights from the "Sugar Code" to biomedical applications. Curr. Med. Chem., v.18, p.2060-2078, 2011.

FIGDOR, C.G.; VAN KOOYK, Y.; ADEMA, G.J. C-type lectin receptors on dendritic cells and langerhans cells. Nature Rev. Immunol., v.2, p.77-84, 2002.

FINN, O.J. Cancer vaccines: between the idea and the reality. Nat. Rev. Immunol., v.3, p.630-641, 2003.

FIORE, M.; THOMAS, B.; DULÉRY, V.; DUMY, P.; RENAUDET, O. Synthesis of multi-antigenic platforms as vaccine candidates against cancers. New J. Chem., v.37, p.286-289, 2013.

FRANCO, A. Glycoconjugates as vaccines for cancer immunotherapy: clinical trials and future directions. Anticancer Agents Med. Chem., v.8, p.86-91, 2008.

FREIRE, T.; BAY, S.; VICHIER-GUERRE, S.; LO-MAN, R.; LECLERC, C. Carbohydrate antigens: synthesis aspects and immunological applications in cancer. Mini Rev. Med. Chem., v.6, p.1357-1373, 2006.

GALAN, M.C.; BENITO-ALIFONSO, D.; WATT, G.M. Carbohydrate chemistry in drug discovery. Org. Biomol. Chem., v.9, p.3598-3610, 2011.

GALAN, M.C.; DUMY, P.; RENAUDET, O. Multivalent glyco(cyclo)peptides. Chem. Soc. Rev., v.42, p.4599-4612, 2013.
GARCIA, I.; GALLO, J.; MARRADI, M.; PENADÉS, S. Glyconanoparticles: New nanomaterials for biological applications. In: NARRAIN, R. (Ed). Engineered carbohydrate-based materials for biomedical applications: Polymers, surfaces, dendrimers, nanoparticles, and hydrogels. Hoboken: John Wiley \& Sons, 2011. chap.6, p.213-259.

GARCIA, I.; MARRADI, M.; PENADÉS, S. Glyconanoparticles: multifunctional nanomaterials for biomedical applications. Nanomedicine-UK, v.5, p.777-792, 2010.

GIGUERE, D.; SATO, S.; ST-PIERRE, C.; SIROIS, S.; ROY, R. Aryl $O$ - and $S$-galactosides and lactosides as specific inhibitors of human galectins-1 and -3: role of electrostatic potential at O-3. Bioorg. Med. Chem. Lett., v.16, p.16681672, 2006a.

GIGUERE, D.; PATNAM, R.; BELLEFLEUR, M.-A.; STPIERRE, C.; SATO, S.; ROY, R. Carbohydrate triazoles and isoxazoles as inhibitors of galectins-1 and -3. Chem. Commun., p.2379-2384, 2006b.

GIGUERE, D.; BONIN, M.-A.; CLOUTIER, P.; PATNAM, R.; ST-PIERRE, C.; SATO, S.; ROY, R. Synthesis of stable and selective inhibitor of human galectins-1 and -3. Bioorg. Med. Chem. Lett., v.16, p.7811-7823, 2008.

GIGUERE, D.; ANDRE, S.; BONIN, M.-A.; BELLEFLEUR, M.-A.; PROVENÇAL, A.; CLOUTIER, P.; PUCCI, B.; ROY, R.; GABIUS, H.-J. Inhibotory potential of chemical substitutions at bioinspired sites of $\beta$-D-galactopyranose on neoglycoprotein/cell surface binding of two classes of medically relevant lectins. Bioorg. Med. Chem. Lett., v.19, p.3280-3287, 2011.

GLINSKII, O.V.; SUD, S.; MOSSINE, V.V.; MAWHINNEY, T.P.; ANTHONY, D.C.; GLINSKY, G.V.; PIENTA, K.J.; GLINSKY, V.V. Inhibition of prostate cancer bone metastasis by synthetic TF antigen mimic/galectin-3 inhibitor lactulose-L-Leucine. Neoplasia, v.14, n.1, p.6573, 2012.

GLINSKY, G.V.; MOSSINE, V.V.; PRICE, J.E.; BIELENBERG, D.; GLINSKY, V.V.; ANANTHASWAMY, H.N.; FEATHER, M.S. Inhibition of colony formation in agarose of metastatic human breast carcinoma and melanoma cells by synthetic glycoamine analogs. Clin. Exp. Metastasis, v.14, p.253-267, 1996. 
GOUIN, S.G.; WELLENS, A.; BOUCKAERT, J.; KOVENSKY, J. Synthetic multimeric heptyl mannosides as potent antiadhesives of uropathogenic Escherichia coli. ChemMedChem, v.4, p.749-755, 2009.

GUO, Z.; BOONS, G.-J. (Eds). Carbohydrate-based vaccines and immunotherapies. Hoboken, New Jersey: John Wiley \& Sons, 2009. 416 p.

GUO, Z.; WANG, Q. Recent development in carbohydratebased cancer vaccines. Curr. Opin. Chem. Biol., v.13, p.608-617, 2009.

HAKOMORI, S. Tumor-associated carbohydrate antigens defining tumor malignancy: basis for development of anticancer vaccines. Adv. Exp. Med. Biol., v.491, p.369-402, 2001.

HARTMANN, M.; LINDHORST, T.K. The bacterial lectin FimH, a target for drug discovery - carbohydrate inhibitors of type 1 Fimbriae-Mediated bacterial adhesion. Eur. J. Org. Chem., p.3583-3609, 2011.

HATTRUP, C.L.; GENDLER, S.J. Structure and function of the cell surface (tethered) mucins. Annu. Rev. Physiol., v.70, p.431-457, 2008.

HEIMBURG, J.; YAN, J.; MOREY, S.; GLINSKII, O.V.; HUXLEY, V.H.; WILD, L.; KLICK, R.; ROY, R.; GLINSKY, V.V.; RITTENHOUSE-OLSON, K. Inhibition of spontaneous breast cancer metastasis by anti-thomsenfriedenreich antigen monoclonal antibody JAA-F11. Neoplasia, v.8, p.939-948, 2006.

HEIMBURG-MOLINARO, J.; ALMOGREN, A.; MOREY, S.; GLINSKII, O.V.; ROY, R.; WILDING, G.E.; CHENG, R.P.; GLINSKY, V.V.; RITTENHOUSE-OLSON, K. Development, characterization, and immunotherapeutic use of peptide mimics of the Thomsen-Friedenreich carbohydrate antigen. Neoplasia, v.11, p.780-792, 2009.

ICART, L.P.; FERNANDEZ-SANTANA, V.; VELOSO, R.C.; CARMENATE, T.; SIROIS, S.; ROY, R.; VEREZ BENCOMO, V. T-cell immunity of carbohydrates: In: ROY, R. (Ed). Carbohydrate-based vaccines. Washington: ACS Symp. Ser., 2008. v.989, chap.1, p.1-19.

IMBERTY, A.; CHABRE, Y.M.; ROY, R. Glycomimetics and glycodendrimers as high affinity microbial anti-adhesins. Chem. Eur. J., v.14, p.7490-7499, 2008.
JIMÉNEZ BLANCO, J.L.; MELLET, C.O.; GARCÍA FERNÁNDEZ, J.M. Multivalency in heterogeneous glycoenvironments: hetero-glycoclusters, -glycopolymers and-glycoassemblies. Chem. Soc. Rev., v.42, p.4518-4531, 2013.

KAISER, A.; GAIDZIK, N.; BECKER, T.; MENGE, C.; GROH, K.; CAI, H.; LI, Y.-M.; GERLITZKI, B.; SCHMITT, E.; KUNZ, H. Fully synthetic vaccines consisting of tumorassociated MUC1 glycopeptides and a lipopeptide ligand of the Toll-like receptor 2. Angew. Chem. Int. Ed., v.49, p.3688-3692, 2010.

KANG, J.Y.; NAN, X.; JIN, M.S.; YOUN, S.-J.; RYU, Y.H.; MAH, S.; HAN, S.H.; LEE, H.; PAIK, S.-G.; LEE, J.-O. Recognition of lipopeptide patterns by Toll-like receptor 2-Toll-like receptor 6 heterodimer. Immunity, v.31, p.873$884,2009$.

KOGANTY, R.R.; YALAMATI, D.; JIANG, Z.-H. Glycopeptide-based cancer vaccines: The role of synthesis and structural definition. In: ROY, R. (Ed). Carbohydratebased vaccines. Washington: ACS Symp. Ser., 2008. v.989, chap.14, p.311-334.

KOTTARI, N.; CHABRE, Y.M.; SHARMA, R.; ROY, R. Application of glyconanoparticles as "Sweet" glycobiological therapeutics and diagnostics. Adv. Polym. Sci., 2013, DOI: 10.1007/12_2012_208.

KUDRYASHOV, V.; GLUNZ, P.W.; WILLIAMS, L.J.; HINTEMANN, S.; DANISHEFSKY, S.J. Toward optimized carbohydrate-based anticancer vaccines: Epitope clustering, carrier structure, and adjuvant all influence antibody responses to Lewis ${ }^{\mathrm{y}}$ conjugates in mice. Proc. Natl. Acad. Sci. USA, v.98, p.3264-3269, 2001.

LIAKATOS, A.; KUNZ, H. Synthetic glycopetides for the development of cancer vaccines. Curr. Opin. Mol. Ther., v.9, p.35-44, 2007.

LIVINGSTON, P.O. Approachs to augmenting the immunogenicity of melanoma gangliosides: from whole melanoma cells to ganglioside-KLH conjugate vaccines. Immunol. Rev., v.145, p.147-166, 1995.

LIVINGSTON, P.O.; RAGUPATHI, G. Carbohydrate vaccines that induce antibodies against cancer. 2. Previous experience and future plans. Cancer Immunol. Immunother.: CII, v.45, p.10-19, 1997. 
MARRADI, M.; CHIODO, F.; GARCÍA, I.; PENADÉS, S. Glyconanoparticles as multifunctional and multimodal carbohydrate systems. Chem. Soc. Rev., v.42, p.4728-4745, 2013.

MARRADI, M.; CHIODO, F.; GARCÍA, I.; PENADÉS, S. Synthesis and biological applications of glycoconjugates. In: RENAUDET, O.; SPINELLI, N. (Eds). Glycoliposomes and metallic glyconanoparticles in glycoscience. City: Bentham Science Publishers, 2010. chap. 5, p.164.

MARRADI, M.; GARCIA, I.; PENADÉS, S. Carbohydratebased nanoparticles for potential applications in medicine. Prog. Mol. Biol. Transl. Sci., v.104, p.141-173, 2011.

MARRADI, M.; MARTÍN-LOMAS, M.; PENADÉS, S. Glyconanoparticles: polyvalent tools to study carbohydratebased interactions. Adv. Carbohydr. Chem. Biochem., v.64, p.211-290, 2010.

MARTÍNEZ, Á.; MELLET, C.O.; GARCÍA FERNÁNDEZ, J.M. Cyclodextrin-based multivalent glycodisplays: covalent and supramolecular conjugates to assess carbohydrate-protein interactions. Chem. Soc. Rev., v.42, p.4746-4773, 2013.

MORELLI, L.; POLETTI, L.; LAY, L. Carbohydrates and immunology: synthetic oligosaccharide antigens for vaccine formulation. Eur. J. Org. Chem., v.29, p.5723-5777, 2011.

NAGAHORI, N.; LEE, R.T.; NISHIMURA, S.-I.; PAGÉ, D.; ROY, R.; LEE, Y.C. Inhibition of adhesion of type 1 fimbriated Escherichia coli to hight mannosylated ligands. ChemBioChem, v.3, p.836-844, 2002.

NARAIN, R. (Ed). Engineered carbohydrate-based materials for biomedical applications. Polymers, surfaces, dendrimers, nanoparticles, and hydrogels. Hoboken: John Wiley \& Sons, 2011. 424 p.

ÖBERG, C.T.; LEFFLER, H.; NILSSON, U.J. Inhibition of galectins with small molecules. Chimia, v.65, p.18-23, 2011.

PAPADOPOUlOS, A.; SHIAO, T.C.; ROY, R. Diazo transfer and click chemistry in the solid phase syntheses of lysine-based glycodendrimers as antagonists against Escherichia coli FimH. Mol. Pharmaceutics, v.9, p.394-403, 2012.
PARK, B.S.; SONG, D.H.; KIM, H.M.; CHOI, B.-S.; LEE, H.; LEE, J.-O. The structural basis of lipopolysaccharide recognition by the TLR4-MD-2 complex. Nature, v.458, p.1191-1195, 2009.

PERI, F. Clustered carbohydrates in synthetic vaccines. Chem. Soc. Rev., v.42, p.4543-4556, 2013.

RAGUPATHI, G. Carbohydrate antigens as targets for active specific immunotherapy. Cancer Immunol. Immunother., v.43, p.152-157, 1996.

REICHARDT, N.C.; MARTÍN-LOMAS, M.; PENADÉS, S. Glyconanotechnology. Chem. Soc. Rev., v.42, p.4358-4376, 2013.

RENAUDET, O.; BENMOHAMED, L.; DASGUPTA, G.; BETTAHI, I.; DUMY, P. Towards a self-adjuvanting multivalent $\mathrm{B}$ and $\mathrm{T}$ cell epitope containing synthetic glycolipopeptide cancer vaccine. ChemMedChem, v.3, p.737-741, 2008.

RENAUDET, O.; DASGUPTA, G.; BETTAHI, I.; SHI, A.; NESBUM, A.B.; DUMY, P.; BENMOHAMED, L. Linear and branched glyco-lipopeptide vaccines follow distinct cross-presentation pathways and generate different magnitudes of antitumor immunity. PLoS ONE, v.5, p.e11216, 2010.

RITTENHOUSE-DIAKUN, K.; XIA, Z.; PICKHARDT, D.; BAEK, M.-G.; ROY, R. Development and characterization of monoclonal antibody to T-antigen: (Galß1-3GalNAca-O). Hybridoma, v.17, p.165-173, 1998.

RÖCKENDORF, N.; LINDHORST, T.K. Glycodendrimers. Top. Curr. Chem., v.217, p.201-238, 2001.

ROY, R. A decade of glycodendrimer chemistry. Trends Glycosci. Glycotechnol., v.15, p.291-310, 2003.

ROY, R. (Ed). Carbohydrate-based vaccines. Washington: ACS Symp. Ser., 2008. v.989, 379 p.

ROY, R. New trends in carbohydrate-based vaccines. Drug Discovery Today: Technologies, v.1, p.327-336, 2004.

ROY, R.; BAEK, M.-G.; RITTENHOUSE-OLSON, K. Synthesis of N,N'-bis(Acrylamido)acetic acid-based T-antigen glycodendrimers and their mouse monoclonal IgG antibody binding properties. J. Am. Chem. Soc., v.123, p.1809-1816, 2001. 
ROY, R.; SHIAO, T.C. Organic chemistry and immunochemical strategies in the design of potent carbohydrate-based vaccines. Chimia, v.65, p.24-29, 2011.

SANSONE, F.; CASNATI, A. Multivalent glycocalixarenes for recognition of biological macromolecules: glycocalyx mimics capable of multitasking. Chem. Soc. Rev., v.42, p.4623-4639, 2013.

SHIAO, T.C.; ROY, R. Glycodendrimers as functional antigens and antitumor vaccines. New J. Chem., v.36, p.324-339, 2012.

SIROIS, S.; GIGUERE, D.; ROY, R. A first QSAR model for galectin-3 glycomimetic inhibitors based on 3D docked structures. Med. Chem., v.2, p.481-489, 2006.

SPOHN, R.; BUWITT-BECKMANN, U.; BROCK, R.; JUNG, G.; ULMER, A.J.; WIESMUELLER, K.-H. Synthetic lipopeptide adjuvants and Toll-like receptor 2-structureactivity relationships. Vaccine, v.22, p.2494-2499, 2004.

SPRINGER, G.F. T and Tn, general carcinoma autoantigens. Science, v.224, p.1198-1206, n.4654, 1984.

ST-PIERRE, C.; OUELLET, M.; GIGUERE, D.; OHTAKE, R.; ROY, R.; SATO, S.; TREMBLAY, M.J. Galectin-1specific inhibitors as a new class of compounds to treat HIV-a infection. Antimicrob. Agents Chemother., v.56, p.154-162, 2012.

SUNDGREN, A.; BARCHI JR., J.J. Varied presentation of the Thomsen-Friedenreich disaccharide tumor-associated carbohydrate antigen on gold nanoparticles. Carbohydr. Res., v.343, p.1594-1604, 2008.

SVAROVSKY, S.A.; BARCHI JR, J.J. De novo synthesis of biofunctional carbohydrate-encapsulated quantum dots. ACS Symp. Ser., v.960, p.375-392, 2007.

SVAROVSKY, S.A.; SZEKELY, Z.; BARCHI JR, J.J. Synthesis of gold nanoparticles bearing the Thomsen-Friedenreich disaccharide: a new multivalent presentation of an important tumor antigen. Tetrahedron: Asymmetry, v.16, p.587-598, 2005.
TOUAIBIA, M.; ROY, R. Glycodendrimers as anti-adhesin drugs against type 1 fimbriated $E$. coli uropathogenic infections. Mini-Rev. Med. Chem., v.7, p.1270-1283, 2007.

TOUAIBIA, M.; ROY, R. First synthesis of "MajoralType" glycodendrimers bearing covalently bound $\alpha$-D-mannopyranoside residues onto a hexachlocyclotriphosphazene core. J. Org. Chem., v.73, p.9292-9302, 2008.

TOUAIBIA, M.; ROY, R. Application of multivalent mannosylated dendrimers in glycobiology. In: KAMERLING, J.P. (Ed). Comprehensive glycoscience. Carbohydrate-protein and carbohydrate-carbohydrate interactions. Elsevier, 2007. v.3, chap.3.36, p.821-870.

TOYOKUNI, T.; DEAN, B.; CAI, S.; BOIVIN, D.; HAKOMORI, S.-I.; SINGHAL, K. Synthetic vaccines: synthesis of a dimeric Tn antigen-lipopeptide conjugate that elicits immune responses against Tn-expressing glycoproteins. J. Am. Chem. Soc., v.116, p.395-396, 1994.

TOYOKUNI, T.; SINGHAL, A.K. Synthetic carbohydrate vaccines based on tumour-associated antigens. Chem. Soc. Rev., v.24, p.231-242, 1995.

VAN HATTUM, H.; BRANDERHORST, H.M.; MORET, E.E.; NILSSON, U.J.; LEFFLER, H.; PIETERS, R.J. Tuning the preference of thiodigalactoside- and lactosamine-based ligands to galectin-3 over galectin-1. J. Med. Chem., v.56, p.1350-1354, 2013.

WANG, X.; RAMSTRÖM, O.; YAN, M. Glyconanomaterials: synthesis, characterization, and ligand presentation. Adv. Mater., v.22, p.1946-1953, 2010.

WESTERLIND, U.; KUNZ, H. Synthetic vaccines from tumorassociated glycopeptide antigens. Chimia, v.65, p.30-34, 2011.

WILSON, R.M.; WARREN, J.D.; OUERFELLI, O.; DANISHEFSKY, S.J. Synthetic carbohydrate-based antitumor vaccines. In: ROY, R. (Ed). Carbohydrate-based vaccines. Washington: ACS Symp. Ser., 2008. v.989, chap.12, p.258-292. 